\title{
Main drivers of transparent exopolymer particle distribution across the surface Atlantic Ocean
}

\author{
Marina Zamanillo $^{1}$, Eva Ortega-Retuerta ${ }^{1,2}$, Sdena Nunes $^{1}$, Pablo Rodríguez-Ros ${ }^{1}$, Manuel Dall'Osto ${ }^{1}$, \\ Marta Estrada $^{1}$, Maria Montserrat Sala ${ }^{1}$, and Rafel Simó ${ }^{1}$ \\ ${ }^{1}$ Biologia Marina i Oceanografia, Institut de Ciències del Mar, CSIC, Barcelona, Catalonia, Spain \\ ${ }^{2}$ CNRS, Sorbonne Université, UMR 7621, Laboratoire d'Océanographie Microbienne, Banyuls-sur-Mer, France
}

Correspondence: Rafel Simó (rsimo@icm.csic.es)

Received: 25 July 2018 - Discussion started: 21 August 2018

Revised: 12 December 2018 - Accepted: 30 December 2018 - Published: 6 February 2019

\begin{abstract}
Transparent exopolymer particles (TEPs) are a class of gel particles, produced mainly by microorganisms, which play important roles in biogeochemical processes such as carbon cycling and export. TEPs (a) are colonized by carbon-consuming microbes; (b) mediate aggregation and sinking of organic matter and organisms, thereby contributing to the biological carbon pump; and (c) accumulate in the surface microlayer (SML) and affect air-sea gas exchange. The first step to evaluate the global influence of TEPs in these processes is the prediction of TEP occurrence in the ocean. Yet, little is known about the physical and biological variables that drive their abundance, particularly in the open ocean. Here we describe the horizontal TEP distribution, along with physical and biological variables, in surface waters along a north-south transect in the Atlantic Ocean during October-November 2014. Two main regions were separated due to remarkable differences: the open Atlantic Ocean (OAO, $n=30$ ), and the Southwestern Atlantic Shelf (SWAS, $n=10$ ). TEP concentration in the entire transect ranged $18.3-446.8 \mu \mathrm{g} \mathrm{XGeq} \mathrm{L}^{-1}$ and averaged $117.1 \pm 119.8 \mu \mathrm{g} \mathrm{XG} \mathrm{eq} \mathrm{L}^{-1}$, with the maximum concentrations in the SWAS and in a station located at the edge of the Canary Coastal Upwelling (CU), and the highest TEP to chlorophyll $a$ (TEP : Chl $a$ ) ratios in the OAO $(183 \pm 56)$ and CU (1760). TEPs were significantly and positively related to Chl $a$ and phytoplankton biomass, expressed in terms of $\mathrm{C}$, along the entire transect. In the OAO, TEPs were positively related to some phytoplankton groups, mainly Synechococcus. They were negatively related to the previous $24 \mathrm{~h}$ averaged solar irradiance, suggesting that sunlight, particularly UV radiation, is more a sink than a source for TEP. Mul-
\end{abstract}

tiple regression analyses showed the combined positive effect of phytoplankton and heterotrophic prokaryotes (HPs) on TEP distribution in the OAO. In the SWAS, TEPs were positively related to high nucleic acid-containing prokaryotic cells and total phytoplankton biomass, but not to any particular phytoplankton group. Estimated TEP-carbon constituted an important portion of the particulate organic carbon pool in the entire transect $(28 \%-110 \%)$, generally higher than the phytoplankton and HP carbon shares, which highlights the importance of TEPs in the cycling of organic matter in the ocean.

\section{Introduction}

Transparent exopolymer particles (TEPs) are defined as a class of nonliving organic particles in aqueous media, mainly consisting of acidic polysaccharides, which are stainable with Alcian Blue (Alldredge et al., 1993). They are formed from dissolved precursors that self-assemble to form TEPs (operationally defined as particles $>0.4 \mu \mathrm{m}$ ) (Passow and Alldredge, 1994; Chin et al., 1998; Thuy et al., 2015). TEPs are stabilized by covalent links or ionic strength (CisternasNovoa et al., 2015) and, therefore, the formation and fragmentation of TEPs from/to dissolved precursor material spans the dissolved-to-particulate continuum of organic matter in the sea. Due to their stickiness, TEPs favor the formation of large aggregates of organic matter and organisms (typically named marine snow), enhancing particle ballast and sinking and thereby contributing to the biological carbon pump (Logan et al., 1995; Kumar et al., 1998; Passow et al., 
2001; Burd and Jackson, 2009). The presence of TEPs also affects the microbial food-web, as they can be used as a food source for zooplankton (Decho and Moriarty, 1990; Dilling et al., 1998; Ling and Alldredge, 2003) and heterotrophic prokaryotes (HPs) (Passow, 2002b) through microbial colonization of aggregates (Alldredge et al., 1986; Grossart et al., 2006; Azam and Malfatti, 2007). On their way to aggregation, and due to their low density, TEPs and TEP-rich microaggregates formed near the surface may ascend and accumulate in the sea surface microlayer (SML) (Engel and Galgani, 2016), a process that is largely enhanced by bubbleassociated scavenging (Azetsu-Scott and Passow, 2004; Wurl et al., 2009, 2011b). This accumulation in the SML, also contributed by local TEP production (Wurl et al., 2011b), can suppress the air-sea exchange of $\mathrm{CO}_{2}$ and other trace gases by acting as a physicochemical barrier or modifying sea surface hydrodynamics at low wind speeds (Calleja et al., 2009; Cunliffe et al., 2013; Wurl et al., 2016). Sea surface TEPs can also be released to the atmosphere by bubble bursting (Zhou et al., 1998; Aller et al., 2005; Kuznetsova et al., 2005), contributing to organic aerosol and possibly acting as cloud condensation nuclei and ice-nucleating particles (Orellana et al., 2011; Leck et al., 2013; Wilson et al., 2015). All in all, TEPs play important roles in microbial diversity, carbon cycling and carbon exports to both the deep ocean and the atmosphere.

TEP distribution in marine systems depends on the complex balance between the sources and the sinks (Alldredge et al., 1998; Passow, 2002a). TEP sinks include some of the abovementioned processes (sinking of aggregates to the deep ocean, release to the atmosphere and consumption by organisms), and also photolysis by UV radiation (Ortega-Retuerta et al., 2009b). Regarding the sources, TEPs are produced by organisms, mainly microorganisms, during metabolic and decomposition processes (Hong et al., 1997; BermanFrank et al., 2007). Phytoplankton are major TEP producers in the ocean, although HPs are also able to produce TEPs (Biddanda, 1986; Stoderegger and Herndl, 1998; Passow, 2002b; Ortega-Retuerta et al., 2010). Some phytoplankton groups that have been shown to produce TEPs include cyanobacteria (Grossart et al., 1998; Mazuecos, 2015; Deng et al., 2016); diatoms (Passow and Alldredge, 1994; Mari and Kiorboe, 1996; Passow, 2002b); dinoflagellates (Passow and Alldredge, 1994); Prymnesiophyceae, including coccolithophores (Riebesell et al., 1995; Engel, 2004; Leblanc et al., 2009); and Cryptomonads (Kozlowski and Vernet, 1995; Passow et al., 1995). Other organisms such as Posidonia oceanica (Iuculano et al., 2017a), zooplankton (Passow and Alldredge, 1999; Prieto et al., 2001) and benthic suspension feeders (Heinonen et al., 2007) have also been identified as TEP producers.

TEP sources and sinks in the ocean depend not only on the taxonomic composition of TEP producers, but they are also influenced by other variables such as the organism's physiological state (Passow, 2002b), temperature (Nicolaus et al., 1999; Claquin et al., 2008), light (Trabelsi et al., 2008; Ortega-Retuerta et al., 2009a; Iuculano et al., 2017b), carbon dioxide concentration (Engel, 2002), nutrient availability (Guerrini et al., 1998; Radic et al., 2006), turbulence (Passow, 2000, 2002b), microbe-microbe interactions (Gärdes et al., 2011) or viral infection (Shibata et al., 1997; Vardi et al., 2012). For example, limitation by nutrients often increases TEP production, due to dissolved inorganic carbon overconsumption (Corzo et al., 2000; Engel et al., 2002a; Schartau et al., 2007), and also impedes prokaryotic consumption of TEPs (Bar-Zeev and Rahav, 2015). High solar radiation can stimulate TEP production by Prochlorococcus during cell decay (Iuculano et al., 2017b), but also can limit TEP formation inhibiting the aggregation of the precursor polymers (Orellana and Verdugo, 2003). HPs have been found to stimulate TEP production by diatoms, suggesting that HPdiatom interaction is required for TEP formation (Guerrini et al., 1998; Gärdes et al., 2011). HPs may also facilitate the self-assembly of dissolved TEP precursors (Sugimoto et al., 2007), e.g., through the release of amphiphilic exopolymers that induce microgel formation (Ding et al., 2008).

The aforementioned importance of TEPs in carbon fluxes in the pelagic ocean can be further stressed by considering the following rough numbers: if the percentage of extracellular carbon release during planktonic primary production is generally constrained within 10\%-20\% (Nagata, 2000; Mari et al., 2017), but can reach $>50 \%$ (López-Sandoval et al., 2011), and half of the extracellular release is in the form of reactive polysaccharides (Biddanda and Benner, 1997), then the production rate of TEP precursors may represent $5 \%-$ $10 \%$, but can reach $>25 \%$ of planktonic primary production, without considering production by heterotrophs. This calls for the need to quantify their occurrence across the oceans, elucidate their main distribution drivers and determine their contribution to the organic carbon reservoir. To date, large-scale studies of TEP distributions in the ocean are scarce, particularly in the open ocean. In this study, we describe the horizontal distribution of TEPs $(>0.4 \mu \mathrm{m})$ in surface waters across a north-south transect in the Atlantic Ocean, including several biogeographical provinces in the open ocean as well as the highly productive Southwestern Atlantic Shelf (SWAS). Our aims were (a) to identify the main biological and abiotic drivers of TEP distribution across contrasting environmental conditions, and (b) to quantify the TEP contribution to the total particulate organic carbon (POC) pool and compare it with those of phytoplankton and heterotrophic prokaryote biomasses.

\section{Material and methods}

\subsection{Study site and sampling}

Sampling was conducted during the TransPEGASO cruise aboard the Spanish R/V Hespérides, from 20 October to 


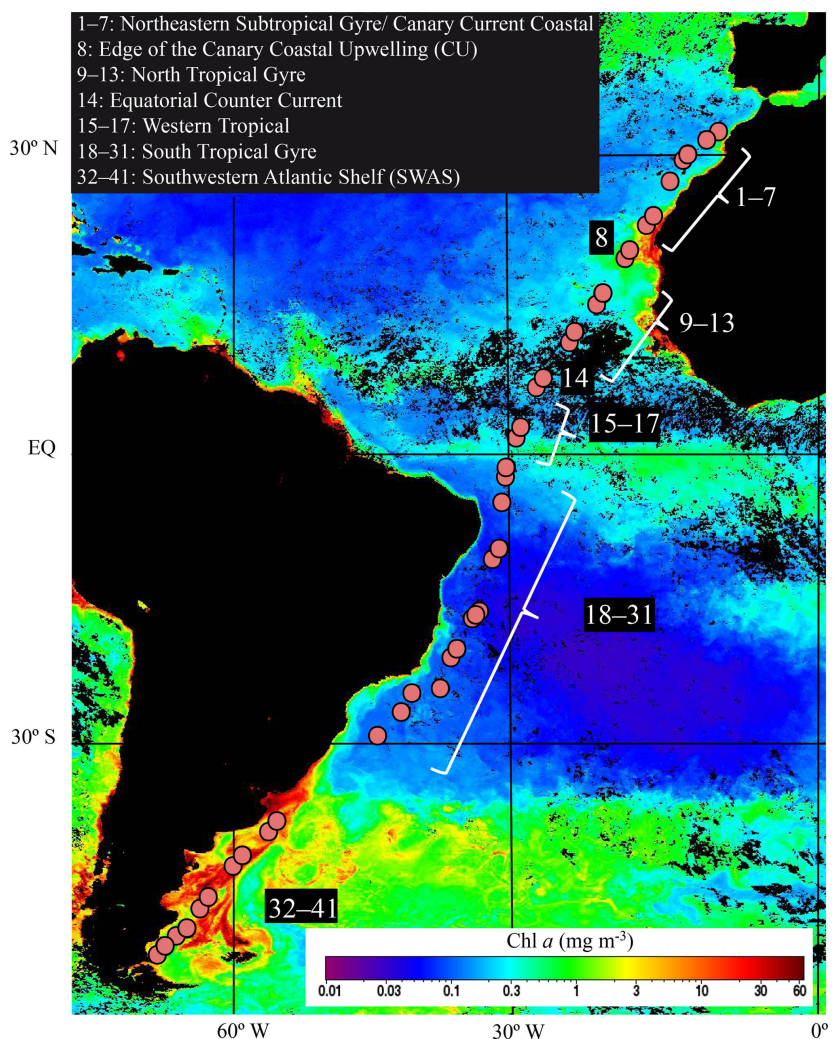

Figure 1. Hydrographic stations (filled circles) of the TransPEGASO cruise, sampled during October-November 2014 in the Atlantic Ocean. Chl $a$ concentration (background color; $\mathrm{mg} \mathrm{m}^{-3}$ ) values during November 2014 were taken from a NASA MODIS Aqua $9 \mathrm{~km}$ product composite.

21 November 2014. A total of 41 stations were sampled within a transit across the Atlantic Ocean from Cartagena (SE Spain) to Punta Arenas (S Chile, Fig. 1). During the cruise, the ship crossed six biogeographical provinces (Longhurst, 1998): the Northeastern Subtropical Gyre, the Canary Current Coastal, the North Atlantic Tropical Gyre, the Western Tropical Atlantic, the South Tropical Gyre and the SWAS. Seawater was collected from $4 \mathrm{~m}$ depth using the ship's underway pump (BKMKC-10.11, Tecnium, Manresa, Spain) and screened through a $150 \mu \mathrm{m}$ Nylon mesh to remove large particles. Temperature and salinity were measured continuously using a SBE21 Sea Cat Thermosalinograph. Solar irradiance was also measured continuously using a LI-COR Biospherical PAR Sensor. The rest of the variables were collected twice a day (09:00:00 and 16:00:00 local time) with the ship moving at approximately 10 knots.

\subsection{Chemical and biological analysis}

\subsubsection{Particulate organic matter (TEP and POC)}

TEP concentrations were determined by spectrophotometry following Passow and Alldredge (1995). Duplicate samples
$(100-500 \mathrm{~mL}$ each) were filtered through $25 \mathrm{~mm}$ diameter $0.4 \mu \mathrm{m}$ pore size polycarbonate filters (DHI) using a constant low filtration pressure $(\sim 150 \mathrm{~mm} \mathrm{Hg})$. The samples were immediately stained with $500 \mu \mathrm{L}$ of Alcian Blue solution $(0.02 \%, \mathrm{pH} 2.5)$ for $5 \mathrm{~s}$ and rinsed with Milli-Q water. The filters were stored frozen until further processing in the laboratory (within 8 months). Duplicate blanks (empty filters stained as stated earlier) were prepared twice a day to correct the interference of stained particles in TEP estimates. Both the sample and blank filters were soaked in $5 \mathrm{~mL}$ of $80 \%$ sulfuric acid for $3 \mathrm{~h}$. The filters were shaken intermittently during this period. The samples were then measured spectrophotometrically at $787 \mathrm{~nm}$ (Varian Cary 100 Bio). The absorbance values of filter blanks did not change substantially between batches of samples, suggesting stability in the staining capacity of the Alcian Blue solution throughout the cruise. The Alcian Blue dye solution was calibrated just before the cruise using a standard solution of xanthan gum (XG) passed through a tissue grinder and subsequently filtered through two sets of filters (four points in triplicate): preweighted filters to determine the actual concentration of the XG solution, and filters that were subsequently stained, frozen and analyzed in the spectrophotometer. The detection limit was set to 0.034 absorbance units and the mean range between duplicates was $18.7 \%$. We estimated the TEP carbon content (TEP-C) using the conversion factor of $0.51 \mu \mathrm{g}$ TEP-C L ${ }^{-1}\left(\mu \mathrm{g} \mathrm{XG} \mathrm{eq} \mathrm{L}{ }^{-1}\right)^{-1}$ (Engel and Passow, 2001).

POC was measured by filtering $1000 \mathrm{~mL}$ of seawater on precombusted $\left(4 \mathrm{~h}, 450^{\circ} \mathrm{C}\right) \mathrm{GF} / \mathrm{F}$ glass fibre filters (Whatman). The filters were stored frozen $\left(-20^{\circ} \mathrm{C}\right)$ until processed. Prior to analysis, the filters were dried at $60^{\circ} \mathrm{C}$ for $24 \mathrm{~h}$ in an atmosphere of $\mathrm{HCl}$ fumes to remove carbonates. Then filters were dried again and analyzed by hightemperature $\left(900^{\circ} \mathrm{C}\right)$ combustion in an elemental analyzer (Perkin-Elmer $2400 \mathrm{CHN}$ ). No POC replicates were run, but replication in a previous study yielded a coefficient of variation of around $5 \%$.

\subsubsection{Chlorophyll $a(\mathrm{Chl} a)$}

Samples for fluorometric Chl $a$ analyses were filtered $(250 \mathrm{~mL}$ ) on glass fibre filters (Whatman GF/F, $25 \mathrm{~mm}$ diameter) and stored at $-20^{\circ} \mathrm{C}$ until further processing in the ship's laboratory. Pigments were extracted with $90 \%$ acetone at $4{ }^{\circ} \mathrm{C}$ in the dark for $24 \mathrm{~h}$. Fluorescence of extracts was measured according to the procedure described in Yentsch and Menzel (1963), with a calibrated Turner Designs fluorometer. No "phaeophytin" correction was applied.

\subsubsection{Inorganic nutrients}

Samples for dissolved inorganic nutrients (nitrate, phosphate and silicate) were stored in $10 \mathrm{~mL}$ sterile polypropylene bottles at $-20^{\circ} \mathrm{C}$ until analysis. The samples were further 
processed in the laboratory using standard segmented flow analyses with colorimetric detection (Hansen and Grasshoff, 1983), using a Skalar Autoanalyzer.

\subsubsection{Microscopic phytoplankton identification}

We quantified phytoplankton groups by microscopy. Water was fixed with hexamine-buffered formaldehyde solution (4\% final formalin concentration) in a glass bottle, immediately after collection, and then was allowed to settle for $48 \mathrm{~h}$ in a $100 \mathrm{~cm}^{3}$ composite chamber. An inverted microscope (Utermöhl, 1958) was used to enumerate the smaller phytoplankton cells $(<20 \mu \mathrm{m}, 312 \times$ magnification) and the larger phytoplankton cells ( $>20 \mu \mathrm{m}, 125 \times$ magnification). Micro-phytoplankton was identified to the species level when possible, and finally classified into four groups: diatoms, dinoflagellates, coccolithophores and other microplankton cells referred to from now on as "other microalgae". Cell C content was calculated using conversion equations of Menden-Deuer and Lessard (2000), $\log \mathrm{pg} \mathrm{C}_{\text {cell }}^{-1}=\log a(95 \%$ confidence intervals $)+b$ $(95 \%$ confidence intervals $) \times \log$ volume $\left(V ; \mu \mathrm{m}^{3}\right)$ : one for diatoms $\left(\log \mathrm{pgC} \mathrm{Cell}^{-1}=\log -0.541(0.099)+\right.$ $0.811(0.028) \times \log V)$ and one for the other algae groups $\left(\log \mathrm{pg} \mathrm{C}_{\text {cell }}{ }^{-1}=\log -0.665(0.132)+0.939(0.041) \times\right.$ $\log V$ ). Total carbon biomass was calculated from cell $\mathrm{C}$ content and cell abundance. Uncertainty sources for micro-phytoplankton biomass estimates are the conversion factors, biovolume estimates and proper identification based on morphological characteristics, harder for naked cells and those at the lower size edge $(5-10 \mu \mathrm{m})$ (Kozlowski et al., 2011; Cassar et al., 2015).

\subsubsection{Picoplankton abundance}

To enumerate picoplankton cells, samples $(4.5 \mathrm{~mL})$ were fixed with $1 \%$ paraformaldehyde plus $0.05 \%$ glutaraldehyde (final concentrations), for $15 \mathrm{~min}$ at room temperature, deep frozen in liquid nitrogen and stored frozen at $-80^{\circ} \mathrm{C}$. Samples were then analyzed 6 months after the cruise end, using a FACS Calibur (Becton and Dickinson) flow cytometer equipped with a $15 \mathrm{~mW}$ argon-ion laser emitting at $488 \mathrm{~nm}$. Before analysis, samples were thawed and we added $10 \mu \mathrm{L}$ per $600 \mu \mathrm{L}$ sample of a $10^{5} \mathrm{~mL}^{-1}$ solution of yellow-green $0.92 \mu \mathrm{m}$ Polysciences latex beads as an internal standard. Samples were then run at high speed (approx. $75 \mu \mathrm{L} \mathrm{min}^{-1}$ ) for $4 \mathrm{~min}$ with Milli-Q water as a sheath fluid. Three groups of phytoplankton (Prochlorococcus, Synechococcus and picoeukaryotic algae) were distinguished and enumerated on the basis of the differences in their autofluorescence properties and scattering characteristics (Olson et al., 1993; Zubkov et al., 1998). Abundances were converted to biomass $\left(\mu \mathrm{g} \mathrm{L}^{-1}\right)$ using average C-tocell conversion factors gathered in Simó et al. (2009): $51 \pm$ $18 \mathrm{fg} \mathrm{C} \mathrm{cell}^{-1}$ for Prochlorococcus, $175 \pm 73 \mathrm{fg} \mathrm{C}^{-1 l^{-1}}$ for
Synechococcus and $1319 \pm 813 \mathrm{fg} \mathrm{C} \mathrm{cell}^{-1}$ for picoeukaryotes.

\subsubsection{Heterotrophic prokaryotic abundance (HPA)}

Heterotrophic prokaryotic abundance (HPA) was determined by flow cytometry using the same fixing protocol and instrument as for picoplankton. Before analyses, samples were thawed, stained with SYBRGreen I (Molecular Probes) at a final concentration of $10 \mu \mathrm{M}$ and left in the dark for about $15 \mathrm{~min}$. Samples were run at a low flow rate (approximately $15 \mu \mathrm{L} \mathrm{min}^{-1}$ ) for 2 min with Milli-Q water as a sheath fluid. We added $10 \mu \mathrm{L}$ per sample of a $10^{5} \mathrm{~mL}^{-1}$ solution of yellow-green $0.92 \mu \mathrm{m}$ Polysciences latex beads as an internal standard. Heterotrophic prokaryotes were detected by their signature in a plot of side scatter versus FL1 (green fluorescence). HP were enumerated separately as high-nucleic-acid-containing (HNA) and low-nucleic-acidcontaining (LNA) cells, and the prokaryote counts presented are the sum of these two types. Data were gated and counted in the SSC vs. FL1 plot using the BD CellQuest ${ }^{\mathrm{TM}}$ software. HPA was expressed in cells $\mathrm{mL}^{-1}$. Only one replicate was analyzed since standard errors of duplicates are usually very low (around $1.5 \%$ at Pernice et al., 2015). HPA was converted into a carbon unit (HP-C) using the conversion factor of $12 \mathrm{fg} \mathrm{C}$ cell $^{-1}$. Ducklow (2000) summarized the carbon contents of free-living marine bacteria reported in the literature for a number of oceanic regions, bays and estuaries. The average \pm standard deviation for open-ocean regions was $12.3 \pm 2.5 \mathrm{fg} \mathrm{C}$ cell $^{-1}$. A factor of $12 \mathrm{fg} \mathrm{C}^{-1 \mathrm{Cl}^{-1}}$ is equivalent to use the empirical equation proposed by Norland (1993), fg C cell ${ }^{-1}=0.12\left(\mu \mathrm{m}^{3} \text { cell volume }\right)^{0.72}$, for an average bacterial biovolume of $0.04 \mu \mathrm{m}^{3}$.

\subsection{Statistical analyses}

We used R software packages lmodel2 and ggplot2 (RStudio Team, 2016) to test for covariations and to explore the potential controlling variables of TEP distribution across the Atlantic Ocean. We performed pairwise Spearman correlation analyses between TEP and POC concentrations. We performed bivariate and multiple regression analyses (ordinary least squares, OLS) between TEP concentrations and several physical, chemical and biological variables. Data were $\log$ transformed to fulfil the requirements of parametric tests. Ranged major axis (RMA) regression would have been more suitable since there were errors in both our dependent and independent variables. However, we decided to perform OLS regressions for a better comparison of slopes between our study and those available in the literature. The nonparametric Wilcoxon-Mann-Whitney test was carried out to compare variables, like TEPs and POC, among regions. Two main regions were analyzed separately due to remarkable differences in nutrient, Chl $a$ and TEP concentration: the open Atlantic Ocean (OAO, $n=30)$, with exclusion of the single 
sample from the edge of the Canary Coastal Upwelling (CU), which had a much higher TEP concentration; and the SWAS $(n=10)$.

\section{Results}

\subsection{TEP distribution across the surface Atlantic Ocean}

TEP concentrations ranged from 18.3 to $446.8 \mu \mathrm{g} \mathrm{XG} \mathrm{eq} \mathrm{L}^{-1}$ along the entire Atlantic Ocean transect. Across OAO, CU included, nitrate and phosphate concentrations were low and relatively homogeneous (nitrate: $0.47 \pm 0.51 \mu \mathrm{mol} \mathrm{L}^{-1}$; phosphate: $\left.0.11 \pm 0.06 \mu \mathrm{mol} \mathrm{L}^{-1}\right)$. Silicate ranged between 0.20 and $1.42 \mu \mathrm{mol} \mathrm{L}^{-1}$, and presented the minimum concentrations in the CU station and surroundings, and the maximum concentration at station 14. The temperatures ranged from 20.7 to $29.6^{\circ} \mathrm{C}\left(25.6 \pm 23.8^{\circ} \mathrm{C}\right)$, with maximum values in the Equatorial Counter Current $\left(\sim 0-20^{\circ} \mathrm{N}, 29.1-29.6^{\circ} \mathrm{C}\right)$, and minimum values around the $\mathrm{CU}$ and in the southernmost stations of the OAO $\left(22.6-23.6^{\circ} \mathrm{C}\right)$. The salinity ranged between 34.8 and 37.4, with the minimum values in the Equatorial Counter Current and the maximum values around 10$30^{\circ} \mathrm{S}$. The Chl $a$ concentration was low and quite homogeneous $\left(0.36 \pm 0.22 \mathrm{mg} \mathrm{m}^{-3}\right)$, even at the $\mathrm{CU}\left(0.25 \mathrm{mg} \mathrm{m}^{-3}\right)$.

In the Northeastern Subtropical Gyre and the Canary Current Coastal (stations 1 to 7, Fig. 1) Chl $a$ concentration ranged from 0.24 to $0.37 \mathrm{mg} \mathrm{m}^{-3}$. The phytoplankton biomass was generally dominated by Prochlorococcus, with an average of $1.68 \times 10^{5} \pm 0.81 \times 10^{5}$ cells mL $^{-1}$, which corresponded to a biomass of $8.58 \pm 4.16 \mu \mathrm{g} \mathrm{CL}^{-1}$. TEP concentration in this region ranged from 54.2 to $131.7 \mu \mathrm{g} \mathrm{XG} \mathrm{eq} \mathrm{L}^{-1}$ (average 73.9 $\pm 27.3 \mu \mathrm{g} \mathrm{XG} \mathrm{eq} \mathrm{L}^{-1}$ ). In the station 8 we sampled the edge of the CU. The decrease in silicate $(0.26 \mu \mathrm{mol} \mathrm{L}-1)$ was accompanied by a relative increase in diatoms (9.4-fold increase) and dinoflagellates (1.3-fold increase) with respect to surrounding stations (Fig. 2b, e). Prochlorococcus abundance decreased to $9 \times 10^{3}$ cell $\mathrm{mL}^{-1}$ and a biomass of $0.46 \mu \mathrm{g} \mathrm{CL} \mathrm{L}^{-1}$. In this station, TEP concentrations were the highest found along the whole transect $\left(446.7 \mu \mathrm{g} \mathrm{XG} \mathrm{eq} \mathrm{L}{ }^{-1}\right)$ but the Chl $a$ concentration $\left(0.25 \mathrm{mg} \mathrm{m}^{-3}\right)$ was lower than in the neighboring region. Consequently the TEP : Chl $a$ ratio was the highest of the whole transect (1760.4). Moving south, the North Tropical Gyre (stations 9 to 13) showed an increase in silicate concentration, from 0.20 to $0.79 \mu \mathrm{mol} \mathrm{L}^{-1}$. The $\mathrm{Chl} a$ concentration ranged from 0.41 to $0.57 \mathrm{mg} \mathrm{m}^{-3}$ (Fig. 2c). In the northernmost part of this region (stations 9 to 11), phytoplankton biomass was dominated by Synechococcus, with an average

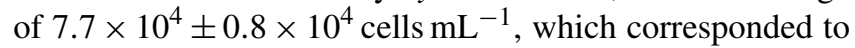
a biomass of $13.5 \pm 1.4 \mu \mathrm{g} \mathrm{CL}^{-1}$. By contrast, the southernmost stations (12 and 13) were dominated by Prochlorococcus, with an average of $2.6 \times 10^{5} \pm 0.5 \times 10^{5}$ cells mL $^{-1}$, that corresponded to a biomass of $13.2 \pm 2.7 \mu \mathrm{g} \mathrm{C} \mathrm{L}^{-1}$ (Fig. 2e). TEP concentrations were similar to those in the North- eastern Subtropical Gyre and the Canary Current Coastal, ranging between 78.1 and $123.9 \mu \mathrm{g} \mathrm{XGeqL}{ }^{-1}$. Station 14 , with a relatively high temperature $\left(29.0^{\circ} \mathrm{C}\right)$ and low salinity (35.2) was probably the most influenced by the Equatorial Counter Current. In this station, the silicate concentration $\left(1.41 \mu \mathrm{mol} \mathrm{L}{ }^{-1}\right)$ was the maximum observed in the whole transect, and there was an increase in dinoflagellates and "other microalgae", and a decrease in Prochlorococcus. The Chl $a$ concentration $\left(0.48 \mathrm{mg} \mathrm{m}^{-3}\right)$ was similar to the surrounding stations and TEPs were $49.4 \mu \mathrm{g} \mathrm{XG} \mathrm{eq} \mathrm{L}{ }^{-1}$. Moving further south, in the Western Tropical and the South Tropical Gyre (stations 15 to 31 ) Chl $a$ ranged from 0.20 to $0.41 \mathrm{mg} \mathrm{m}^{-3}$ and the silicate concentration decreased $(0.42$ $1.39 \mu \mathrm{mol} \mathrm{L}^{-1}$ ). TEP presented the lowest average values of the whole transect, ranging from 25.5 to $80.4 \mu \mathrm{g} \mathrm{XG} \mathrm{eq} \mathrm{L}{ }^{-1}$. Overall in the OAO (excluding CU), TEPs ranged from 18.3 to $131.7 \mu \mathrm{g} \mathrm{XG} \mathrm{eq} \mathrm{L}^{-1}$ (average $59.9 \pm 27.4 \mu \mathrm{g} \mathrm{XG} \mathrm{eq} \mathrm{L}^{-1}$ ) and the TEP : Chl $a$ ratio ranged between 81 and 360 (average $183 \pm 56$; Table 1 ).

The southernmost part of the cruise transect corresponded to the SWAS (stations 32 to 41 ). In this region, temperature $\left(7.6-13.9^{\circ} \mathrm{C}\right)$ and salinity $(32.6-33.6)$ were lower on average than those found in the OAO (Table 1). The SWAS could be further divided into two regions according to different inorganic nutrient (nitrate and phosphate) concentrations $(p<0.05)$ and phytoplankton composition. The northern SWAS (stations 32 to 36 ) presented lower nitrate (0.16 to $\left.4.15 \mu \mathrm{mol} \mathrm{L}^{-1}\right)$ and phosphate $\left(0.31\right.$ to $\left.0.62 \mu \mathrm{mol} \mathrm{L}^{-1}\right)$ concentrations than the southern SWAS (stations 37 to 41; nitrate: 2.16 to $8.92 \mu \mathrm{mol} \mathrm{L}^{-1}$, phosphate: 0.51 to $\left.0.89 \mu \mathrm{mol} \mathrm{L}^{-1}\right)$. Silicate was more homogeneous throughout (0.31 to $\left.1.27 \mu \mathrm{mol} \mathrm{L}^{-1}\right)$. Chl $a$ concentration across the entire SWAS $\left(1.07-3.75 \mathrm{mg} \mathrm{m}^{-3}\right.$ ) was significantly higher than in the OAO, with no major differences between the northern and the southern parts. In most of the northern SWAS, phytoplankton biomass was dominated by "other microalgae", with an average of $10.2 \times 10^{5} \pm 6.1 \times 10^{5}$ cells L ${ }^{-1}$, which corresponded to a biomass of $43.7 \pm 25.8 \mu \mathrm{g} \mathrm{CL}^{-1}$. In station 35 , an increase in diatoms $\left(58121\right.$ cells L $^{-1}$ and a biomass of $145.2 \mu \mathrm{g} \mathrm{C} \mathrm{L}^{-1}$ ) and dinoflagellates (44896 cells L ${ }^{-1}$ and a biomass of $3.3 \mu \mathrm{CLL}^{-1}$ ) was observed, coinciding with a decrease in silicate $\left(0.32 \mu \mathrm{mol} \mathrm{L}^{-1}\right)$. Here in northern SWAS, TEPs ranged from 98.6 to $427.2 \mu \mathrm{g} \mathrm{XG} \mathrm{eq} \mathrm{L}{ }^{-1}$, with the maxima in stations 34 and 35 (Fig. 2f). In the southern SWAS (stations 37 to 41), phytoplankton biomass was dominated by picoeukaryotes, with an average of $6.34 \times 10^{4} \pm 1.93 \times 10^{4}$ cells mL $^{-1}$, which corresponded to a biomass of $83.6 \pm 25.5 \mu \mathrm{g} \mathrm{C} \mathrm{L}{ }^{-1}$. TEP concentration ranged 168.6-395.7 $\mu \mathrm{g} \mathrm{XGeqL}^{-1}$. Overall in the SWAS, TEPs ranged from 98.6 to $427.2 \mu \mathrm{g} \mathrm{Xeq} \mathrm{L}^{-1}$ (average $255.7 \pm$ $130.4 \mu \mathrm{g} \mathrm{XG} \mathrm{eq}^{-1}$ ) and the TEP : Chl $a$ ratio ranged from 31 to 165 (average $97 \pm 42$ ) (Table 1). 
Table 1. Mean, standard deviation and range of temperature $\left({ }^{\circ} \mathrm{C}\right)$, salinity, $24 \mathrm{~h}$ averaged solar irradiance $\left(\mathrm{W} \mathrm{m}^{-2}\right)$, nitrate $\left(\mu \mathrm{mol} \mathrm{L}^{-1}\right)$, silicate $\left(\mu \mathrm{mol} \mathrm{L}{ }^{-1}\right)$, phosphate $\left(\mu \mathrm{mol} \mathrm{L}^{-1}\right)$, Chl $a\left(\mathrm{mg} \mathrm{m}^{-3}\right)$, POC $\left(\mu \mathrm{mol} \mathrm{L}^{-1}\right)$, HPA $\left(\times 10^{5} \mathrm{cells} \mathrm{mL}^{-1}\right)$, TEP $\left(\mu \mathrm{g} \mathrm{XG} \mathrm{eq} \mathrm{L}^{-1}\right)$ and TEP : Chl $a$ in the OAO, the edge of the Canary Coastal Upwelling (CU) and the SW Atlantic Shelf.

\begin{tabular}{|c|c|c|c|c|c|}
\hline & \multicolumn{2}{|l|}{$\mathrm{OAO}$} & \multirow{2}{*}{$\begin{array}{r}\text { CU } \\
\text { Value }(n=1)\end{array}$} & \multicolumn{2}{|l|}{ SW Atlantic Shelf } \\
\hline & Mean \pm SD (ranges) & $n$ & & Mean \pm SD (ranges) & $n$ \\
\hline Temperature $\left({ }^{\circ} \mathrm{C}\right)$ & $26.0 \pm 2.1(22.6-29.6)$ & 30 & 23.6 & $10.7 \pm 2.2(7.6-13.9)$ & 9 \\
\hline Salinity & $36.4 \pm 0.6(34.8-37.4)$ & 30 & 36.1 & $33.2 \pm 0.3(32.6-33.6)$ & 9 \\
\hline Solar irradiance $24 \mathrm{~h}\left(\mathrm{~W} \mathrm{~m}^{-2}\right)$ & $265 \pm 73(144-362)$ & 26 & - & $369 \pm 52(264-425)$ & 10 \\
\hline Nitrate $\left(\mu \mathrm{mol} \mathrm{L}{ }^{-1}\right)$ & $0.49 \pm 0.53(0.09-0.77)$ & 30 & 0.13 & $4.08 \pm 3.08(0.16-8.9)$ & 10 \\
\hline Silicate $\left(\mu \mathrm{mol} \mathrm{L}^{-1}\right)$ & $0.74 \pm 0.27(0.20-1.41)$ & 30 & 0.26 & $0.63 \pm 0.35(0.31-1.27)$ & 10 \\
\hline Phosphate $(\mu \mathrm{mol} \mathrm{L}-1)$ & $0.11 \pm 0.06(0.05-0.18)$ & 30 & 0.16 & $0.57 \pm 0.21(0.31-0.89)$ & 10 \\
\hline Chl $a\left(\mathrm{mg} \mathrm{m}^{-3}\right)$ & $0.32 \pm 0.10(0.20-0.57)$ & 29 & 0.25 & $2.73 \pm 0.87(1.07-3.75)$ & 10 \\
\hline $\mathrm{POC}(\mu \mathrm{mol} \mathrm{L}-1)$ & $4.2 \pm 1.9(1.7-7.1)$ & 12 & - & $16.6 \pm 15.8(6.8-44.3)$ & 5 \\
\hline $\mathrm{HPA}\left(\times 10^{5}\right.$ cells $\left.\mathrm{mL}^{-1}\right)$ & $7.83 \pm 2.16(4.34-14.90)$ & 30 & 14.56 & $29.04 \pm 5.39(13.00-70.20)$ & 10 \\
\hline TEPs $\left(\mu \mathrm{g} X \mathrm{X} \mathrm{eq} \mathrm{L}^{-1}\right)$ & $59.8 \pm 27.4(18.3-131.7)$ & 30 & 446.8 & $255.7 \pm 130.4(98.6-427.2)$ & 10 \\
\hline TEP : Chl $a$ & $183.1 \pm 55.8(81.2-359.7)$ & 29 & 1760.4 & $97.2 \pm 42.1(30.8-164.9)$ & 10 \\
\hline
\end{tabular}

\subsection{TEP contribution to POC}

TEPs and POC covaried significantly and positively across the entire TransPEGASO transect (Spearman rs analysis, $r=0.91, p<0.01, n=17)$. The contribution of TEP-C to the POC pool (TEP-C\%POC) ranged between $34 \%$ and $103 \%$ in the OAO (average $66 \pm 19 \%$ ), and between $28 \%$ and $110 \%$ in the SWAS (average $73 \pm 36 \%$ ). POC was not analyzed in the $\mathrm{CU}$ (Fig. 3). To better explore the importance of TEP-C with respect to other major quantifiable POC pools, we estimated phytoplankton biomass (phyto-C) and HP biomass (HP-C) throughout the whole cruise (Fig. 2). It is worth mentioning that POC also includes other fractions of nonliving non-TEP organic carbon (e.g., cell fragments and Coomassie stainable particles), but phytoplankton and heterotrophic prokaryotes are generally considered the most abundant in open sea water (Ortega-Retuerta et al., 2009b; Yamada et al., 2015). TEP-C contributed the most to the POC pool in the OAO, where it represented twice the share of phyto-C and HP-C. In the SWAS, conversely, TEP$\mathrm{C}$ was not significantly different than phyto-C, and was 3 times higher than HP-C (Fig. 3).

\subsection{Relationship to other variables}

TEPs were significantly and positively related to Chl $a$ along the entire transect $\left(R^{2}=0.61, p<0.001, n=39\right.$, Table 3$)$. The regression equation for $\log$ converted TEP vs. Chl $a$ was $\log$ TEP $=2.09( \pm 0.04)+0.66( \pm 0.08) \times \log$ Chl $a$. Considering the two study regions separately, only in the OAO was the relationship significant, with a higher slope than in the entire transect $(\log \mathrm{TEP}=2.31( \pm 0.10)+1.13( \pm 0.20) \times \log \mathrm{Chl} a$; $R^{2}=0.56, p<0.001, n=29$ ).

Across the whole transect, TEPs presented a significant $(p<0.05)$ positive relationship with total phytoplankton biomass (Table 3) and with some phytoplankton biomass groups: Synechococcus $\left(R^{2}=0.30\right)$, picoeukaryotes $\left(R^{2}=\right.$ $0.49)$, diatoms $\left(R^{2}=0.19\right)$ and "other microalgae" $\left(R^{2}=\right.$ $0.27)$, and with HPA $\left(R^{2}=0.60\right)$. TEPs were negatively related to silicate $\left(R^{2}=0.19\right)$ and coccolithophores $\left(R^{2}=\right.$ 0.15 ). Some differences arose from examining the two regions separately. Within the OAO, TEPs presented a significant $(p<0.001)$ positive relationship with $\mathrm{Chl} a\left(R^{2}=\right.$ $0.56)$, total phytoplankton biomass $\left(R^{2}=0.47\right)$ and some phytoplankton groups (Synechococcus, picoeukaryotes, diatoms, dinoflagellates and "other microalgae", Table 3), but not with HPA. TEPs showed a significant $(p<0.001)$ negative relationship with the previous $24 \mathrm{~h}$ averaged solar irradiance $\left(R^{2}=0.43\right.$, Fig. 4). Multiple regression analyses showed the combined positive effect of Chl $a$ and HPA on TEP distribution in the OAO (Table 4). By contrast, within the SWAS, TEPs only presented a significant $(p<0.05)$ positive relationship with total phytoplankton biomass $\left(R^{2}=\right.$ $0.62)$ and HNA $\left(R^{2}=0.46\right.$, Table 3$)$.

\section{Discussion}

\subsection{TEPs across the surface Atlantic Ocean}

We present the first distribution of surface $(4 \mathrm{~m})$ TEP concentration along a latitudinal gradient in the Atlantic Ocean, covering both open sea and shelf waters. It is worth mentioning that vertical variability within the top surface meters $(<4 \mathrm{~m})$ has sometimes been observed (Wurl et al., 2009), but $4 \mathrm{~m}$ is usually considered "surface ocean" in studies where samples are collected with either an oceanographic rosette or an underway pumping system. The existing information about TEP distribution in surface waters of the open oceans is compiled in Table 2. The TEP concentrations that we measured across the OAO (CU included) generally fall within 


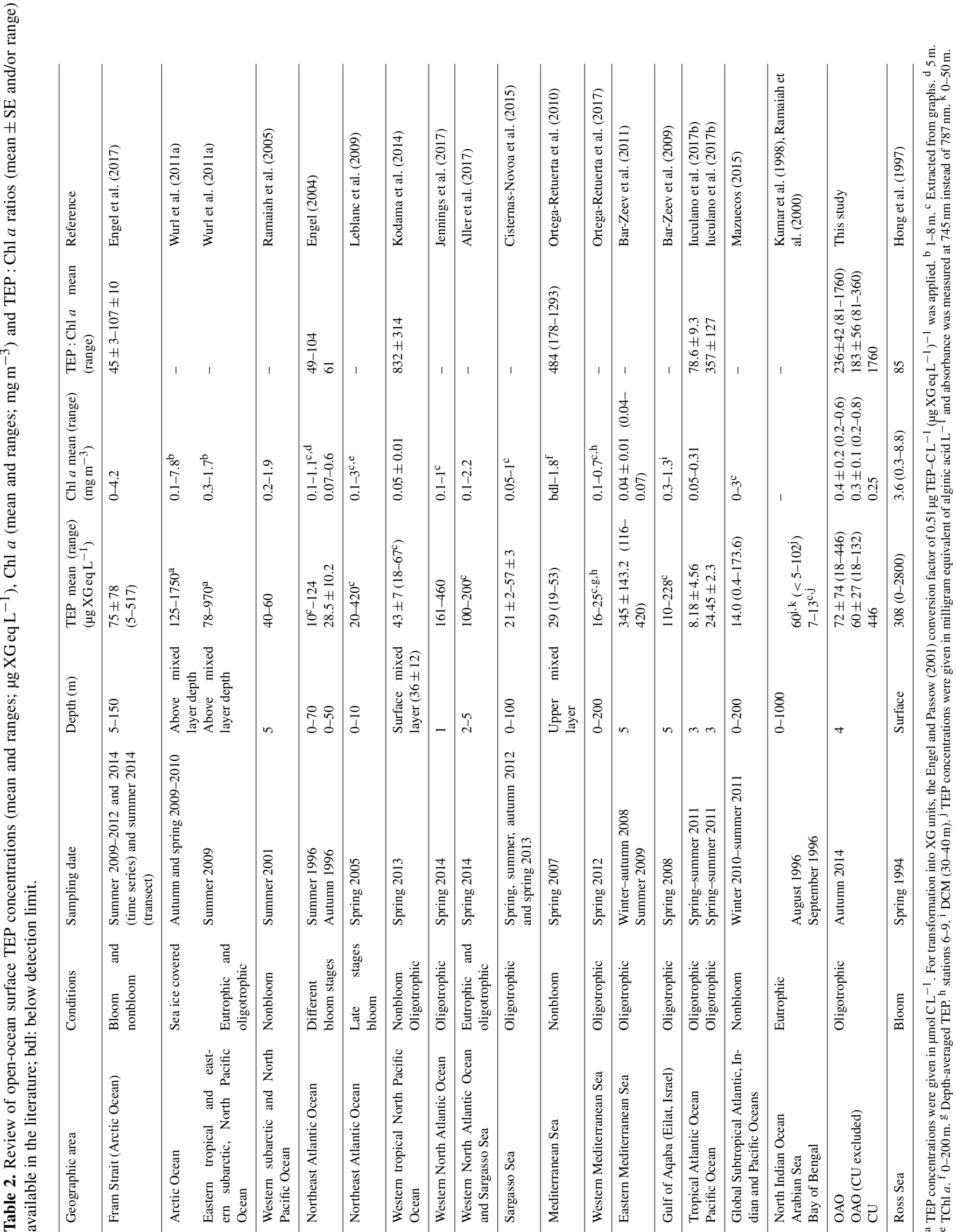




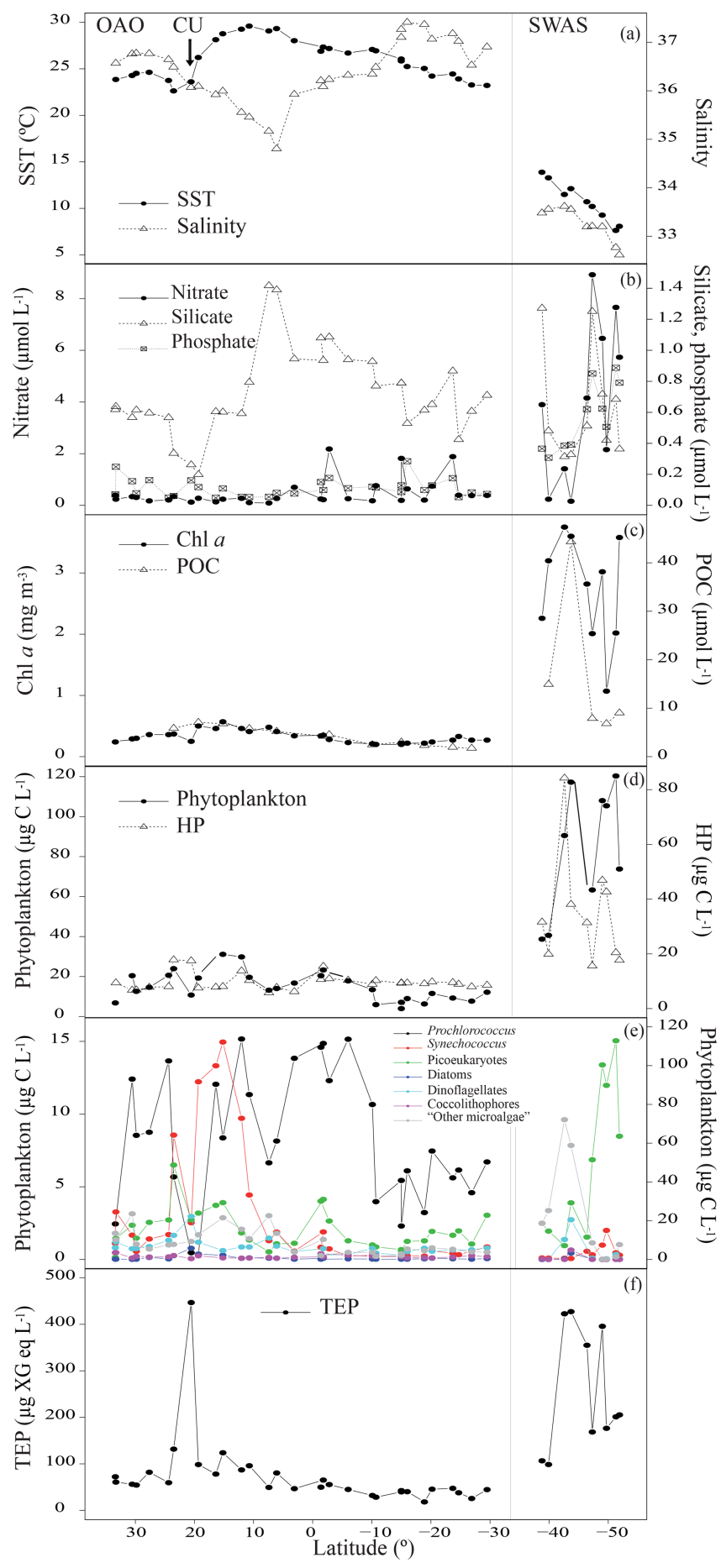

Figure 2. Variations of sea surface temperature $\left(\mathrm{SST},{ }^{\circ} \mathrm{C}\right)$ and salinity (a); nitrate, silicate and phosphate $\left(\mu \mathrm{mol} \mathrm{L}{ }^{-1}\right)$ (b); Chl $a$ $\left(\mathrm{mg} \mathrm{m}^{-3}\right)$ and POC $\left(\mu \mathrm{mol} \mathrm{L}{ }^{-1}\right)(\mathbf{c})$; biomass of phytoplankton and $\mathrm{HP}\left(\mu \mathrm{g} \mathrm{C} \mathrm{L}^{-1}\right)(\mathbf{d})$; biomass of Prochlorococcus, Synechococcus, picoeukaryotes, diatoms, dinoflagellates, coccolithophores and "other microalgae" ( $\left.\mu \mathrm{g} \mathrm{C} \mathrm{L}^{-1}\right)$. OAO (left axis) and SWAS (right axis) (e) and TEPs ( $\mu \mathrm{g} \mathrm{XG} \mathrm{eq}^{-1}$ ) (f) in the TransPEGASO cruise.

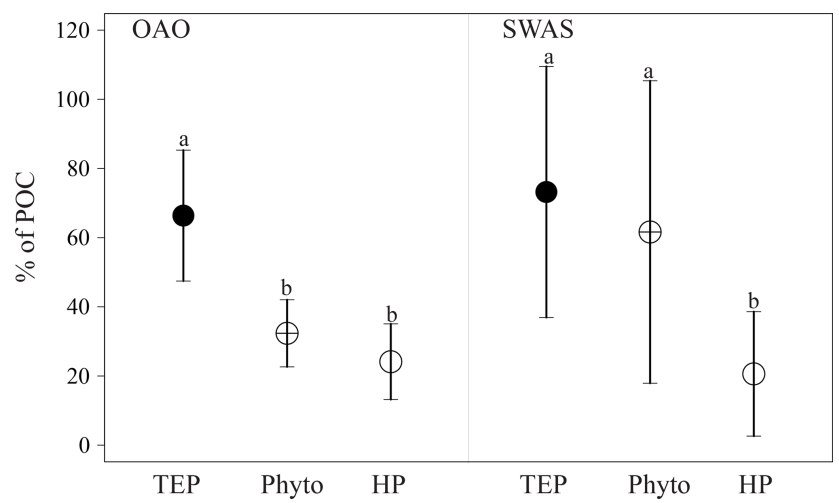

Figure 3. Average and standard deviation of the contribution of TEP, phytoplankton and HP to the POC pool (\%) in the OAO and the SWAS.

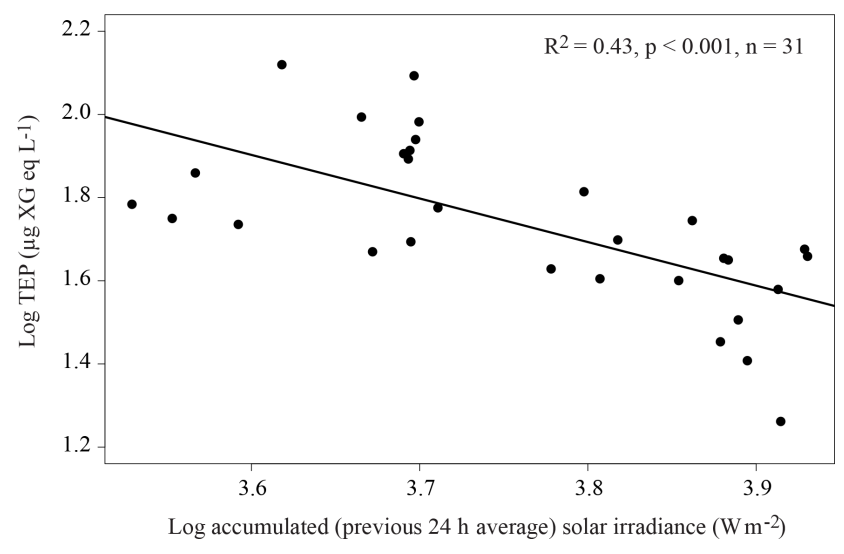

Figure 4. Relationship between the $24 \mathrm{~h}$-average (previous to sampling) solar irradiance $\left(\mathrm{W} \mathrm{m}^{-2}\right)$ and TEP $\left(\mu \mathrm{g} \mathrm{XG} \mathrm{eq} \mathrm{L}{ }^{-1}\right)$ in the OAO (CU sample excluded). The linear regression line is plotted and the equation indicated.

the range reported in other studies from the open ocean (Table 2). However, our levels are higher than those observed in the Mediterranean Sea (Ortega-Retuerta et al., 2010, 2017), Pacific Ocean (Ramaiah et al., 2005; Kodama et al., 2014; Iuculano et al., 2017b) and one study in the northwestern Atlantic Ocean (Cisternas-Novoa et al., 2015), and lower than that reported in the eastern Mediterranean Sea (BarZeev et al., 2011). We believe that one of the reasons for the higher values found in our study compared with these previous studies is the depth. Mean TEP values in some of them (Ortega-Retuerta et al., 2010; Kodama et al., 2014; CisternasNovoa et al., 2015; Ortega-Retuerta et al., 2017) correspond to the above mixed layer depth or from 0 to 100 or $200 \mathrm{~m}$. As TEPs tend to accumulate in the surface and our values correspond only to the surface $(4 \mathrm{~m})$, this could explain the higher values obtained in our dataset. Another reason seems to be the different Chl $a$ concentrations, as the main TEP producer is phytoplankton. $\mathrm{Chl} a$ concentration in the OAO $\left(0.4 \pm 0.2 \mathrm{mg} \mathrm{m}^{-3}\left(0.2-0.6 \mathrm{mg} \mathrm{m}^{-3}\right)\right)$ was generally higher 
than in the other studies referred in the Table 2. For example, in Iuculano et al. (2017b) Chl $a$ ranged $0.05-0.31 \mathrm{mg} \mathrm{m}^{-3}$, and in Kodama et al. (2014) it averaged $0.05 \pm 0.01 \mathrm{mg} \mathrm{m}^{-3}$. We also cannot discard the possibility that differences in TEP chemical composition could cause differences in staining capacity.

We found maximum TEP concentrations in the regions with high nutrient supply, namely in the station located in the CU and within the SWAS. Ours are the first TEP concentrations ever measured in the SWAS (Table 1), and only three more studies have reported TEP concentrations in coastal or shelf waters of the Atlantic Ocean (Harlay et al., 2009, 2010; Jennings et al., 2017). The SWAS is a high-nutrient region due to the arrival of cold nutrient-rich subantarctic water with the Malvinas Current. This current collides near $40^{\circ} \mathrm{S}$ with the southward-flowing Brazil Current (Gordon, 1989; Piola and Gordon, 1989; Peterson and Stramma, 1991; Palma et al., 2008). The nutrient-rich water in the region is responsible for the proliferation of phytoplankton and HP, which could partly explain the high TEP concentrations in this region. It is also known that large freshwater discharges occur in the shelf (Piola, 2005). These discharges could bring allochtonous HP directly to the shelf or bring DOM loads, which would stimulate autochtonous microbes. Besides, DOM inputs associated with freshwater discharges could also contain TEPs and their precursors. Although no previous information on TEP distribution exists for this area, previous studies in similarly productive areas or during phytoplankton blooms already observed high TEP concentrations (Long and Azam, 1996; Harlay et al., 2009; Klein et al., 2011). The TEP levels we measured at the SWAS are generally within the range of those reported for coastal areas (Passow and Alldredge, 1995; Passow et al., 1995; Riebesell et al., 1995; Kiorboe et al., 1996; Hong et al., 1997; Jähmlich et al., 1998; Wild, 2000; Ramaiah et al., 2001; Engel et al., 2002b; García et al., 2002; Radic et al., 2005; Scoullos et al., 2006; Sugimoto et al., 2007; Harlay et al., 2009, 2010; Wurl et al., 2009; Fukao et al., 2011; Klein et al., 2011; Sun et al., 2012; Van Oostende et al., 2012; Dreshchinskii and Engel, 2017; Jennings et al., 2017). Only two studies, in the western Baltic Sea and the Dona Paula Bay (Arabian Sea), reported TEP levels higher than ours (Engel, 2000; Bhaskar and Bhosle, 2006).

\subsection{TEPs as an important contributor to ocean surface POC}

The significant positive correlation between TEPs and POC observed in our study highlighted the importance of TEPdetermining POC horizontal variations in the surface Atlantic Ocean, suggesting a high contribution of TEPs to this pool. A few values of TEP-C\%POC were unrealistically higher than $100 \%$, a feature that has also been observed in other studies (Engel and Passow, 2001; Bar-Zeev et al., 2011; Yamada et al., 2015). This suggests the inaccuracy of the use of standard TEP-to-carbon conversion factors (CFs, $0.51 \mu \mathrm{g}$ TEP-
$\mathrm{CL}^{-1}\left(\mu \mathrm{g} X \text { eq } \mathrm{L}^{-1}\right)^{-1}$ in our case). Therefore there is a need to define specific CFs for diverse regions or environmental conditions. Nonetheless, an alternative explanation for the apparent oversizing of the relative TEP-C pool may be strictly methodological: TEPs are determined on filters of $0.4 \mu \mathrm{m}$ pore size, whereas POC is measured on glass fibre filters with nominal pore size of $0.7 \mu \mathrm{m}$. It is plausible, thus, that some of the smaller TEPs are not taken into account in the POC measurement.

All in all, our results clearly show that TEP-C constituted an important portion of the POC pool in the Atlantic Ocean (from $28 \%$ to $110 \%$ ). This contribution is comparable to that reported in the eastern Mediterranean Sea (Bar-Zeev et al., 2011; Parinos et al., 2017), lower than in the western Arctic (Yamada et al., 2015), but higher than in the northeastern Atlantic Ocean (Harlay et al., 2009, 2010). Both in the OAO and SWAS, TEPs comprised the largest share of the POC pool, with phyto-C being equal or the second most important contributor to POC (Fig. 3). Phyto-C surpassed TEP-C in only one station in the SWAS. The contribution of phyto- $\mathrm{C}$ and $\mathrm{HP}-\mathrm{C}$ to the POC pool should be considered with caution, as the glass fibre filters (nominal pore size $0.7 \mu \mathrm{m}$ ) used to analyze POC could have not retained all the small phytoplankton organisms and prokaryotes (Gasol and Morán, 1999), causing underestimation of the actual POC pool. Furthermore, conversion factors carry quite an uncertainty, as pointed out in the Methods section.

A previous study in a eutrophic system reported TEP$\mathrm{C}$ as the dominant POC contributor (Yamada et al., 2015), whereas others found that phyto-C represented the largest share to POC compared to TEP-C and HP-C (Bhaskar and Bhosle, 2006; Ortega-Retuerta et al., 2009b; de Vicente et al., 2010). With our results taken all together, we hypothesize that in oligotrophic conditions TEP-C is the predominant POC fraction, because nutrient limitation favors TEP production by phytoplankton and limits TEP consumption by bacteria. Conversely, in eutrophic conditions, the predominant POC fraction depends on many variables like the community composition, the bloom stage and sources of TEPs other than phytoplankton.

\subsection{Main drivers of TEP distribution in the surface ocean}

In order to better understand and even predict the occurrence of TEPs in the surface ocean, it is important to describe their distribution together with those of their main putative sources (phytoplankton and heterotrophic prokaryotes), sinks and environmental modulators, across large-scale gradients. However, most of the previous studies of TEPs in the Atlantic Ocean were restricted to local areas, and, to our knowledge, only one included a complete description of these variables together in a long transect (Mazuecos, 2015).

Our dataset suggests that phytoplankton is the main driver of TEP distribution in the surface Atlantic Ocean at the hor- 
Table 3. Regression equations and statistics describing the relationship between TEP and different variables throughout the TransPEGASO cruise (note all variables were $\log _{10}$ transformed). $\mathrm{B}=$ biomass. Bold font denotes statistical significance with $p<0.05$.

\begin{tabular}{|c|c|c|c|c|c|c|c|c|c|c|c|c|c|c|c|}
\hline \multirow[t]{2}{*}{ Dep. var. } & \multirow[t]{2}{*}{ Ind. var. } & \multicolumn{5}{|c|}{ Open Atlantic Ocean (CU excluded) } & \multicolumn{5}{|c|}{ SW Atlantic Shelf } & \multicolumn{4}{|c|}{ All } \\
\hline & & $R^{2}$ & $p$ & Intercept & Slope & $n$ & $R^{2}$ & $p$ & Intercept & Slope & $n$ & $R^{2}$ & $p$ & Intercept & Slope \\
\hline \multirow[t]{18}{*}{ TEP } & SST & 0.07 & 0.16 & & & 29 & 0.06 & 0.51 & & & 9 & 0.48 & $<0.001$ & 3.80 & -1.43 \\
\hline & Salinity & 0.26 & $<0.05$ & 21.78 & -12.84 & 29 & 0.002 & 0.90 & & & 9 & 0.57 & $<0.001$ & 25.13 & -14.97 \\
\hline & Solar irradiance $24 \mathrm{~h}$ & 0.43 & $<0.001$ & 5.67 & -1.04 & 30 & 0.08 & 0.40 & & & 10 & 0.02 & 0.33 & & \\
\hline & Nitrate & 0.06 & 0.21 & & & 30 & 0.002 & 0.91 & & & 10 & 0.13 & 0.02 & 1.97 & 0.23 \\
\hline & Phosphate & 0.04 & 0.29 & & & 30 & 0.02 & 0.69 & & & 10 & 0.37 & $<0.001$ & 2.39 & 0.58 \\
\hline & Silicate & 0.07 & 0.15 & & & 30 & 0.24 & 0.15 & & & 10 & 0.19 & $<0.005$ & 1.75 & -0.80 \\
\hline & Chl $a$ & 0.56 & $<0.001$ & 2.31 & 1.13 & 29 & 0.16 & 0.24 & & & 10 & 0.61 & $<0.001$ & 2.09 & 0.66 \\
\hline & HPA & 0.04 & 0.31 & & & 29 & 0.36 & 0.06 & & & 10 & 0.60 & $<0.001$ & -4.28 & 1.03 \\
\hline & HNA & 0.01 & 0.57 & & & 29 & 0.46 & 0.03 & -0.44 & 0.46 & 10 & 0.51 & $<0.001$ & -2.31 & 0.75 \\
\hline & LNA & 0.02 & 0.43 & & & 29 & 0.02 & 0.71 & & & 10 & 0.17 & $<0.05$ & -1.96 & 0.68 \\
\hline & Prochlorococcus B & 0.002 & 0.80 & & & 30 & - & - & & & & - & - & & \\
\hline & Synechococcus B & 0.72 & $<0.001$ & 1.72 & 0.28 & 30 & 0.005 & 0.84 & & & 10 & 0.30 & $<0.001$ & 1.87 & 0.34 \\
\hline & Picoeukaryotes B & 0.15 & $<0.05$ & 1.68 & 0.23 & 30 & 0.005 & 0.84 & & & 10 & 0.49 & $<0.001$ & 1.71 & 0.37 \\
\hline & Diatoms B & 0.37 & $<0.001$ & 2.11 & 0.28 & 27 & 0.42 & 0.058 & 2.55 & 0.16 & 9 & 0.19 & $<\mathbf{0 . 0 5}$ & 2.23 & 0.25 \\
\hline & Dinoflagellates B & 0.18 & $<0.05$ & 1.79 & 0.40 & 27 & 0.30 & 0.13 & & & 9 & 0.08 & 0.08 & & \\
\hline & Coccolithophores B & 0.01 & 0.59 & & & 27 & 0.002 & 0.90 & & & 9 & 0.15 & $<0.05$ & 1.70 & -0.23 \\
\hline & "Other microalgae" B & 0.40 & $<0.001$ & 1.75 & 0.39 & 27 & 0.0002 & 0.97 & & & 9 & 0.27 & $<0.001$ & 1.86 & 0.28 \\
\hline & Phytoplankton B & 0.47 & $<0.001$ & 1.04 & 0.61 & 26 & 0.62 & $<0.05$ & 0.43 & 1.00 & 9 & 0.62 & $<0.001$ & 0.99 & 0.70 \\
\hline
\end{tabular}

$R^{2}$ : explained variance; $n$ : sample size; $p$ : level of significance.

izontal scale, since significant positive relationships were observed between TEPs and both $\mathrm{Chl} a$ and phytoplankton biomass (Table 3). It is worth noting that Chl $a$ was a good estimator of phytoplankton biomass when the entire cruise was considered, as these variables were tightly related $\left(R^{2}=0.79, p\right.$ value $\left.<0.001, n=36\right)$. The slope of the $\log$ converted TEP-Chl $a$ relationship for the whole study ( $\beta=$ $0.66 \pm 0.08$, Table 3 ) was within the upper range amongst published data (Fig. 5), and the slope in the OAO $(\beta=$ $1.13 \pm 0.20$ ) was the highest reported so far (Table 3, Fig. 5). In the SWAS, the TEP-Chl $a$ relationship was not significant ( $p$ value $>0.05$ ), yet it was for TEP-phytoplankton biomass (see below).

TEP : Chl $a$ ratios were significantly $(p<0.001)$ higher in the OAO (both including or excluding the $\mathrm{CU}$ ) than in the SWAS (Table 1), with the maximum value in the station located in the CU. TEP : $\mathrm{Chl} a$ values in the OAO (CU included) were comparable to those observed in other oligotrophic areas (Riebesell et al., 1995; García et al., 2002; Prieto et al., 2006; Harlay et al., 2009; Ortega-Retuerta et al., 2010; Kodama et al., 2014; Iuculano et al., 2017b; Parinos et al., 2017) (Table 2), while the values in the SWAS were comparable to those reported in eutrophic waters (Hong et al., 1997; Ramaiah et al., 2001; Engel et al., 2002b; Corzo et al., 2005; Ortega-Retuerta et al., 2009b). The higher TEP : Chl $a$ ratios in oligotrophic waters (Prieto et al., 2006) are related to nutrient scarcity, which is suggested to enhance TEP production by phytoplankton and prokaryotes (Myklestad, 1977; Guerrini et al., 1998; Mari et al., 2005; Beauvais et al., 2006). The highest TEP : Chl $a$ ratio of the entire transect observed in the station located in the CU was probably associated with the high relative abundance of diatoms and dinoflagellates. These groups are known to be strong TEP producers

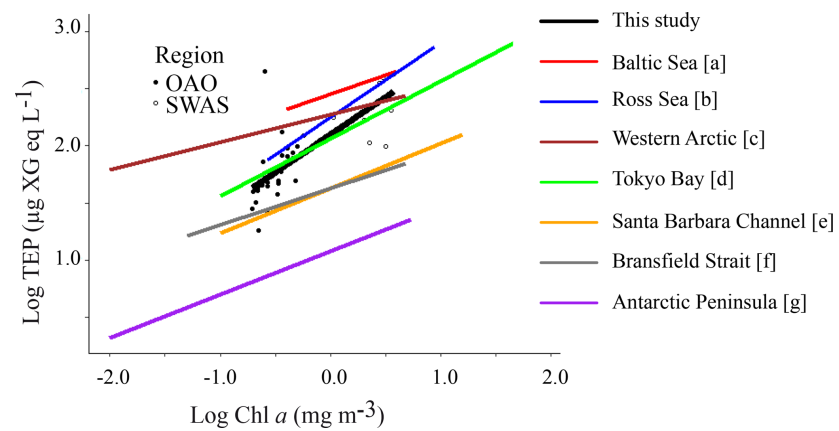

Figure 5. Relationship between TEP and Chl $a$ concentration from the TransPEGASO cruise, with the linear regression line (regression equation in the text). Two regions are distinguished: open Atlantic Ocean (OAO, CU included, filled circles) and SW Atlantic Shelf (SWAS, empty circles). Regression lines from the literature are also shown for comparison. $\alpha$ and $\beta$ indicate the $y$ intercept and slope, respectively; $\log$ TEP $\left(\mu \mathrm{g} \mathrm{XG} \mathrm{eq} \mathrm{L}{ }^{-1}\right)=\alpha+\beta \times \log$ Chl $a$ ( $\mathrm{mg} \mathrm{m}^{-3}$ ); (a) $\alpha=2.45$ and $\beta=0.33$, (Engel, 1998 in Passow, 2002a); (b) $\alpha=2.25$ and $\beta=0.65$, (Hong et al., 1997); (c) $\alpha=$ 2.27 and $\beta=0.24$, (Yamada et al., 2015); (d) $\alpha=2.06$ and $\beta=$ 0.50 , (Ramaiah and Furuya, 2002); (e) $\alpha=1.63$ and $\beta=0.39$, (Passow and Alldredge, 1995); (f) $\alpha=1.63$ and $\beta=0.32$, (Corzo et al., 2005); (g) $\alpha=1.08$ and $\beta=0.38$, (Ortega-Retuerta et al., 2009b).

(Passow and Alldredge, 1994), and besides, previous studies have shown that TEP production rates reach maxima at late stages of the growth cycle, once nutrients have been exhausted (Corzo et al., 2000; Pedrotti et al., 2010; Borchard and Engel, 2015). In the CU, the relatively low Chl $a$ level along with low silicate concentrations suggests that the upwelling-triggered bloom maximum had already passed, which resulted in a high TEP : Chl $a$ ratio. Although POC 
Table 4. Results of multiple regression analyses between TEPs and combined variables, all $\log _{10}$ transformed. Bold font denotes statistical significance with $p<0.05$.

\begin{tabular}{|c|c|c|c|c|c|c|c|c|c|c|c|c|c|}
\hline \multirow[t]{2}{*}{ Dep. var. } & \multirow[t]{2}{*}{ Ind. var. } & \multicolumn{4}{|c|}{ OAO (CU excluded) } & \multicolumn{4}{|c|}{ SWAS } & \multicolumn{4}{|c|}{ All } \\
\hline & & $\begin{array}{r}\text { Partial } \\
\text { coefficient }\end{array}$ & $\begin{array}{r}\text { Partial } \\
p\end{array}$ & $R^{2}$ & $p$ & $\begin{array}{r}\text { Partial } \\
\text { coefficient }\end{array}$ & $\begin{array}{r}\text { Partial } \\
p\end{array}$ & $R^{2}$ & $p$ & $\begin{array}{r}\text { Partial } \\
\text { coefficient }\end{array}$ & $\begin{array}{r}\text { Partial } \\
p\end{array}$ & $R^{2}$ & $p$ \\
\hline \multirow[t]{4}{*}{ TEPs } & $\begin{array}{l}\text { Phyto B } \\
\text { HPA }\end{array}$ & $\begin{array}{l}0.67 \\
0.14\end{array}$ & $\begin{array}{r}<0.001 \\
0.58\end{array}$ & 0.53 & $<0.001$ & $\begin{array}{l}0.82 \\
0.38\end{array}$ & $\begin{array}{r}<0.05 \\
0.13\end{array}$ & 0.66 & $<0.05$ & $\begin{array}{l}0.47 \\
0.48\end{array}$ & $\begin{array}{l}<0.01 \\
<0.05\end{array}$ & 0.68 & $<0.001$ \\
\hline & $\begin{array}{l}\text { Phyto B } \\
\text { HNA }\end{array}$ & $\begin{array}{l}0.70 \\
0.06\end{array}$ & $\begin{array}{r}<0.001 \\
0.70\end{array}$ & 0.53 & $<0.001$ & $\begin{array}{l}0.76 \\
0.28\end{array}$ & $\begin{array}{r}<0.05 \\
0.08\end{array}$ & 0.70 & $<0.05$ & $\begin{array}{l}0.54 \\
0.36\end{array}$ & $\begin{array}{r}<0.001 \\
<0.01\end{array}$ & 0.71 & $<0.001$ \\
\hline & $\begin{array}{l}\text { Chl } a \\
\text { HPA }\end{array}$ & $\begin{array}{l}1.26 \\
0.56\end{array}$ & $\begin{array}{r}<0.001 \\
<0.05\end{array}$ & 0.67 & $<0.001$ & $\begin{array}{l}0.48 \\
0.59\end{array}$ & $\begin{array}{l}0.26 \\
0.08\end{array}$ & 0.33 & 0.10 & $\begin{array}{l}0.39 \\
0.54\end{array}$ & $\begin{array}{r}<0.005 \\
<0.01\end{array}$ & 0.66 & $<0.001$ \\
\hline & $\begin{array}{l}\text { Chl } a \\
\text { HNA }\end{array}$ & $\begin{array}{l}1.28 \\
0.20\end{array}$ & $\begin{array}{r}<0.001 \\
0.20\end{array}$ & 0.60 & $<0.001$ & $\begin{array}{l}0.30 \\
0.42\end{array}$ & $\begin{array}{l}0.48 \\
0.06\end{array}$ & 0.36 & 0.08 & $\begin{array}{l}0.47 \\
0.37\end{array}$ & $\begin{array}{r}<0.001 \\
<0.01\end{array}$ & 0.67 & $<\mathbf{0 . 0 0 1}$ \\
\hline
\end{tabular}

$R^{2}$ : explained variance, $p$ : level of significance.

was not measured in the CU, high TEP : Chl $a$ suggests a high proportion of TEPs with respect to other organic particles. In the SWAS, the lower TEP : Chl $a$ ratios could be related with a lower rate of TEP production under relatively replete nutrient conditions. Extending our comparison to the literature, the TEP : Chl $a$ ratio is generally higher in oligotrophic regions (Prieto et al., 2006; Ortega-Retuerta et al., 2010; Kodama et al., 2014; Iuculano et al., 2017b) than in eutrophic regions (Hong et al., 1997; Engel et al., 2002b, 2017; Corzo et al., 2005; Ortega-Retuerta et al., 2009b; Klein et al., 2011).

In the OAO, the phytoplankton groups that showed a significant $(p<0.05)$ positive relationship to TEPs and hence were candidates to be considered as the main producers of TEPs or their precursors were Synechococcus, picoeukaryotes, diatoms, dinoflagellates and "other microalgae" (Table 3). All the abovementioned groups have been reported to produce TEPs (see references in the introduction). Conversely, coccolithophores and Prochlorococcus did not present a significant relationship with TEP. It has been shown in cultures that coccolithophores do not produce high amounts of TEPs (Passow, 2002b), and a previous study showed temporal disconnections between coccolithophores and TEP maxima (Ortega-Retuerta et al., 2018). However, in a previous study in the Atlantic Ocean, Leblanc et al. (2009) found an association of TEPs with coccolithophores.

The oligotrophic ocean covers a big portion of the global ocean and it is mostly dominated by picophytoplankton (Agawin et al., 2000), chiefly Prochlorococcus and Synechococcus (Partensky et al., 1999). Iuculano et al. (2017b) reported relatively high rates of TEP production by Prochlorococcus in culture, and Mazuecos (2015) found a significant and positive relationship of TEPs with Prochlorococcus abundance in the low-latitude oceans. The absence of significant covariation between TEPs and the abundant Prochlorococcus in our study suggests that these picophytoplankters are not the main TEP producers, or their production is strongly modulated by environmental conditions. It is remarkable that, amongst the phytoplankton groups of the present study, Synechococcus biomass presented the highest correlation $\left(R^{2}=0.72\right)$ with TEP concentration in the OAO. Deng et al. (2016) demonstrated TEP production by marine Synechococcus in a laboratory study, but only Mazue$\cos (2015)$ had previously found a significant and positive relationship $\left(R^{2}=0.26-0.36\right)$ between these two variables in the ocean, particularly in the Atlantic, North Pacific and Indian oceans. This author actually found that Synechococcus was the phytoplankton group with the highest relationship with TEP concentration. Our study supports the importance of Synechococcus as a TEP source in the oligotrophic ocean.

In the SWAS, unlike in the OAO, the significant relationship between TEPs and the total phytoplankton biomass $\left(R^{2}=0.62\right)$ was not accompanied by any relationship to any phytoplankton group (Table 3 ). This could be due to the high variability of the phytoplankton composition in the SWAS stations. Since many phytoplankton taxa are capable of TEP production, it is difficult to discern one group playing the main role. Moreover, as mentioned before, in these shelf waters TEP formation could have been further modulated by aggregation of colloids carried by freshwater discharges.

Regarding the influence of abiotic factors in TEP distribution, we found a negative relationship $\left(R^{2}=0.43\right)$ between TEP concentration and the $24 \mathrm{~h}$ averaged solar irradiance in the OAO (Fig. 4). The OAO stations were exposed to high solar radiation due to water transparency and their location in tropical and subtropical regions. Ultraviolet (UV) radiation causes TEP loss by photolysis (Ortega-Retuerta et al., 2009a) and inhibits TEP formation from precursors (Orellana and Verdugo, 2003). However, it has also been proved that solar radiation harms picophytoplanktonic cells through photobiological stress, inducing TEP production (Agustí and Llabrés, 2007; Iuculano et al., 2017b). Our results suggest that the roles of UV radiation in breaking up TEPs and/or limiting 
their formation from precursors overcome UV stress-induced TEP production.

The role of HPs as potential drivers of TEP distribution is not straightforward, since their net effect on TEP accumulation depends on local conditions. Across the entire transect, TEP concentration was significantly $(p<0.001)$ and positively related to HPA (Table 3 ). However, the relationship was not significant considering the regions separately, and only in the SWAS were TEPs significantly $(p<0.05)$ and positively related to HNA, considered to be a proxy of the more active cells (Servais et al., 1999; Lebaron et al., 2001). This relationship in the SWAS could indicate that HPs used TEPs as a significant carbon source or that both HPs and TEPs were controlled by the same drivers, such as the presence of dissolved polysaccharides, which are substrates for HP as well as TEP precursors (Mari and Kiorboe, 1996). In the OAO, despite the lack of a paired relationship between TEPs and HPA, multiple regression analyses showed that both phytoplankton and HPs contributed significantly to explain TEP concentration variance (Table 4).

In summary, our study describes for the first time the horizontal distribution of TEPs across a north-south transect in the Atlantic Ocean. TEPs constituted a large portion of the POC pool, larger than phytoplankton at most stations and always larger than heterotrophic prokaryotic biomass. This supports the important role of TEPs in the carbon cycle. The drivers of TEP distribution were primarily phytoplankton and, to a lesser extent, heterotrophic prokaryotes among sources, with Synechococcus playing an outstanding role in the oligotrophic ocean. In the oligotrophic ocean, solar irradiance was also a major identifiable sink. We call for the need to carry out more extensive studies in the ocean, across both space and time, in order to better predict the occurrence of TEPs and incorporate diagnostic relationships in model projections. These diagnostic studies must be combined with further process studies if we are to relate TEP concentrations to important biogeochemical processes such as microbial colonization of particles, organic matter export to the deep ocean, gas exchange at the air-water interface and organic aerosol formation.

Data availability. Data are not publicly accessible yet. For further information, please contact the corresponding author.

Author contributions. MZ conducted the field work, analyzed samples, and processed and analyzed the data. EOR and RS designed the study and analyzed data. SN, PRR, ME and MMS analyzed samples and provided data. MD helped with data contextualization. MZ, EOR and RS wrote the paper with the help of all co-authors.

Competing interests. The authors declare that they have no conflict of interest.
Acknowledgements. This research was funded by the Spanish Ministry of Economy and Competitiveness through projects PEGASO (CTM2012-37615) and BIOGAPS (CTM2016-81008-R) to Rafel Simó. Marina Zamanillo was supported by a FPU predoctoral fellowship from the Spanish Ministry of Education and Culture. Eva Ortega-Retuerta was supported by a Marie Curie Actions Intra-European Fellowship (H2020-MSCA-IF-2015-703991). The authors thank Pep Gasol and Carolina Antequera for assistance with flow cytometry; Maximino Delgado for microscopic phytoplankton counts; Rocío Zamanillo and Rafael Campos for assistance with R software; and the scientists, the Marine Technology Unit (UTMCSIC) and crew on board the R/V Hespérides for help during the cruise.

Edited by: S. Wajih A. Naqvi

Reviewed by: two anonymous referees

\section{References}

Agawin, N. S. R., Duarte, C. M., and Agustí, S.: Nutrient and temperature control of the contribution of picoplankton to phytoplankton biomass and production, Limnol. Oceanogr., 45, 591600, 2000.

Agustí, S. and Llabrés, M.: Solar Radiation-induced Mortality of Marine Pico-phytoplankton in the Oligotrophic Ocean, Photochem. Photobiol., 83, 793-801, 2007.

Alldredge, A. L., Cole, J. J., and Caron, D. A.: Production of heterotrophic Inc. bacteria inhabiting macroscopic organic aggregates (marine snow) from surface waters, Limnol. Oceanogr., 31 68-78, 1986.

Alldredge, A. L., Passow, U., and Logan, B. E.: The abundance and significance of a class of large, transparent organic particles in the ocean, Deep-Sea Res. Pt. I, 40, 1131-1140, 1993.

Alldredge, A. L., Passow, U., and Haddock, S. H. D.: The characteristics and transparent exopolymer particle (TEP) content of marine snow formed from thecate dinoflagellates, J. Plankton Res., 20, 393-406, 1998.

Aller, J. Y., Kuznetsova, M. R., Jahns, C. J., and Kemp, P. F.: The sea surface microlayer as a source of viral and bacterial enrichment in marine aerosols, J. Aerosol Sci., 36, 801-812, https://doi.org/10.1016/j.jaerosci.2004.10.012, 2005.

Aller, J. Y., Radway, J. C., Kilthau, W. P., Bothe, D. W., Wilson, T. W., Vaillancourt, R. D., Quinn, P. K., Coffman, D. J., Murray, B. J., and Knopf, D. A.: Size-resolved characterization of the polysaccharidic and proteinaceous components of sea spray aerosol, Atmos. Environ., 154, 331-347, https://doi.org/10.1016/j.atmosenv.2017.01.053, 2017.

Azam, F. and Malfatti, F.: Microbial structuring of marine ecosystems, Nat. Rev. Microbiol., 5, 782-791, https://doi.org/10.1038/nrmicro1747, 2007.

Azetsu-Scott, K. and Passow, U.: Ascending marine particles: Significance of transparent exopolymer particles (TEP) in the upper ocean, Limnol. Oceanogr., 49, 741-748, 2004.

Bar-Zeev, E. and Rahav, E.: Microbial metabolism of transparent exopolymer particles during the summer months along a eutrophic estuary system, Front. Microbiol., 6, 403, https://doi.org/10.3389/fmicb.2015.00403, 2015. 
Bar-Zeev, E., Berman-Frank, I., Stambler, N., Vázquez Domínguez, E., Zohary, T., Capuzzo, E., Meeder, E., Suggett, D. J., Iluz, D., Dishon, G., and Berman, T.: Transparent exopolymer particles (TEP) link phytoplankton and bacterial production in the Gulf of Aqaba, Aquat. Microb. Ecol., 56, 217-225, https://doi.org/10.3354/ame01322, 2009.

Bar-Zeev, E., Berman, T., Rahav, E., Dishon, G., Herut, B., and Berman-Frank, I.: Transparent exopolymer particle (TEP) dynamics in the eastern Mediterranean Sea, Mar. Ecol.-Prog. Ser., 431, 107-118, https://doi.org/10.3354/meps09110, 2011.

Beauvais, C., Pedrotti, M. L., Egge, J., Iversen, K., and Marrasé, C.: Effects of turbulence on TEP dynamics under contrasting nutrient conditions: implications for aggregation and sedimentation processes, Mar. Ecol.-Prog. Ser., 323, 47-57, 2006.

Berman-Frank, I., Rosenberg, G., Levitan, O., Haramaty, L., and Mari, X.: Coupling between autocatalytic cell death and transparent exopolymeric particle production in the marine cyanobacterium Trichodesmium, Environ. Microbiol., 9, 1415-1422, https://doi.org/10.1111/j.1462-2920.2007.01257.x, 2007.

Bhaskar, P. V. and Bhosle, N. B.: Dynamics of transparent exopolymeric particles (TEP) and particle-associated carbohydrates in the Dona Paula bay, west coast of India, J. Earth Syst. Sci., 115, 403-413, https://doi.org/10.1007/bf02702869, 2006.

Biddanda, B. and Benner, R.: Carbon, nitrogen, and carbohydrate fluxes during the production of particulate and dissolved organic matter by marine phytoplankton, Limnol. Oceanogr., 42, 506$518,1997$.

Biddanda, B. A.: Structure and function of marine microbial aggregates, Oceanol. Acta, 9, 209-211, 1986.

Borchard, C. and Engel, A.: Size-fractionated dissolved primary production and carbohydrate composition of the coccolithophore Emiliania huxleyi, Biogeosciences, 12, 1271-1284, https://doi.org/10.5194/bg-12-1271-2015, 2015.

Burd, A. B. and Jackson, G. A.: Particle aggregation, Annu. Rev. Mar. Sci., 1, 65-90, https://doi.org/10.1146/annurev.marine.010908.163904, 2009.

Calleja, M. Ll., Duarte, C. M., Prairie, Y. T., Agustí, S., and Herndl, G. J.: Evidence for surface organic matter modulation of air-sea $\mathrm{CO}_{2}$ gas exchange, Biogeosciences, 6, 1105-1114, https://doi.org/10.5194/bg-6-1105-2009, 2009.

Cassar, N., Wright, S. W., Thomson, P. G., Trull, T. W., Westwood, K. J., de Salas, M., Davidson, A., Pearce, I., Davies, D. M., and Matear, R. J.: The relation of mixed-layer net community production to phytoplankton community composition in the Southern Ocean, Global Biogeochem. Cy., 29, 446-462, https://doi.org/10.1002/2014gb004936, 2015.

Chin, W.-C., Orellana, M. V., and Verdugo, P.: Spontaneous assembly of marine dissolved organic matter into polymer gels, Nature, 391, 568-572, 1998.

Cisternas-Novoa, C., Lee, C., and Engel, A.: Transparent exopolymer particles (TEP) and Coomassie stainable particles (CSP): Differences between their origin and vertical distributions in the ocean, Mar. Chem., 175, 56-71, https://doi.org/10.1016/j.marchem.2015.03.009, 2015.

Claquin, P., Probert, I., Lefebvre, S., and Veron, B.: Effects of temperature on photosynthetic parameters and TEP production in eight species of marine microalgae, Aquat. Microb. Ecol., 51, 1-11, https://doi.org/10.3354/ame01187, 2008.
Corzo, A., Morillo, J. A., and Rodríguez, S.: Production of transparent exopolymer particles (TEP) in cultures of Chaetoceros calcitrans under nitrogen limitation, Aquatic Microb. Ecol., 23, 6372, https://doi.org/10.3354/ame023063, 2000.

Corzo, A., Rodríguez-Gálvez, S., Lubian, L., Sangrá, P., Martínez, A., and Morillo, J. A.: Spatial distribution of transparent exopolymer particles in the Bransfield Strait, Antarctica, J. Plankton Res., 27, 635-646, https://doi.org/10.1093/plankt/fbi038, 2005.

Cunliffe, M., Engel, A., Frka, S., Gašparović, B., Guitart, C., Murrell, J. C., Salter, M., Stolle, C., Upstill-Goddard, R., and Wurl, O.: Sea surface microlayers: A unified physicochemical and biological perspective of the air-ocean interface, Prog. Oceanogr., 109, 104-116, https://doi.org/10.1016/j.pocean.2012.08.004, 2013.

Decho, A. W. and Moriarty, D. J. W.: Bacterial exopolymer utilization by a harpacticoid copepod: A methodology and results, Limnol. Oceanogr., 35, 1039-1049, 1990.

Deng, W., Cruz, B. N., and Neuer, S.: Effects of nutrient limitation on cell growth, TEP production and aggregate formation of marine Synechococcus, Aquat. Microb. Ecol., 78, 39-49, https://doi.org/10.3354/ame01803, 2016.

de Vicente, I., Ortega-Retuerta, E., Mazuecos, I. P., Pace, M. L., Cole, J. J., and Reche, I.: Variation in transparent exopolymer particles in relation to biological and chemical factors in two contrasting lake districts, Aquat. Sci., 72, 443-453, https://doi.org/10.1007/s00027-010-0147-6, 2010.

Dilling, L., Wilson, J., Steinberg, D., and Alldredge, A. L.: Feeding by the euphasiid Euphasia pacifica and the copepod Calanus pacificus on marine snow, Mar. Ecol.-Prog. Ser., 170, 189-201, 1998.

Ding, Y.-X., Chin, W.-C., Rodriguez, A., Hung, C.-C., Santschi, P. H., and Verdugo, P.: Amphiphilic exopolymers from Sagittula stellata induce DOM self-assembly and formation of marine microgels, Mar. Chem., 112, 11-19, https://doi.org/10.1016/j.marchem.2008.05.003, 2008.

Dreshchinskii, A. and Engel, A.: Seasonal variations of the sea surface microlayer at the Boknis Eck Times Series Station (Baltic Sea), J. Plankton Res., 39, 943-961, https://doi.org/10.1093/plankt/fbx055, 2017.

Ducklow, H.: Bacterial production and biomass in the oceans, in: Microbial Ecology of the Oceans, edited by: Kirchman, D. L., Wiley, New York, 2000.

Engel, A.: The role of transparent exopolymer particles (TEP) in the increase in apparent particle stickiness $(\alpha)$ during the decline of a diatom bloom, J. Plankton Res., 22, 485-497, 2000.

Engel, A.: Direct relationship between $\mathrm{CO}_{2}$ uptake and transparent exopolymer particles production in natural phytoplankton, J. Plankton Res., 24, 49-53, 2002.

Engel, A.: Distribution of transparent exopolymer particles (TEP) in the northeast Atlantic Ocean and their potential significance for aggregation processes, Deep-Sea Res. Pt. I, 51, 83-92, https://doi.org/10.1016/j.dsr.2003.09.001, 2004.

Engel, A. and Galgani, L.: The organic sea-surface microlayer in the upwelling region off the coast of Peru and potential implications for air-sea exchange processes, Biogeosciences, 13, 989-1007, https://doi.org/10.5194/bg-13-989-2016, 2016.

Engel, A. and Passow, U.: Carbon and nitrogen content of transparent exopolymer particles (TEP) in relation to their Alcian Blue adsorption, Mar. Ecol. Prog. Ser., 219, 1-10, 2001. 
Engel, A., Goldthwait, S., Passow, U., and Alldredge, A. L.: Temporal decoupling of carbon and nitrogen dynamics in a mesocosm diatom bloom, Limnol. Oceanogr., 47, 753-761, $2002 \mathrm{a}$.

Engel, A., Meyerhöfer, M., and von Bröckel, K.: Chemical and Biological Composition of Suspended Particles and Aggregates in the Baltic Sea in Summer (1999), Estuar. Coast. Shelf S., 55, 729-741, https://doi.org/10.1006/ecss.2001.0927, 2002b.

Engel, A., Piontek, J., Metfies, K., Endres, S., Sprong, P., Peeken, I., Gabler-Schwarz, S., and Nothig, E. M.: Inter-annual variability of transparent exopolymer particles in the Arctic Ocean reveals high sensitivity to ecosystem changes, Sci. Rep., 7, 4129, https://doi.org/10.1038/s41598-017-04106-9, 2017.

Fukao, T., Kitahara, S., Karino, N., Yamatogi, T., Kimoto, K., and Kotani, Y.: Dynamics of transparent exopolymer particles in spring and autumn in Isahaya Bay, Japan, Nippon Suisan Gakk., 77, 1027-1033, 2011.

García, C. M., Prieto, L., Vargas, M., Echevarría, F., GarcíaLafuente, J., Ruiz, J., and Rubín, J. P.: Hydrodynamics and the spatial distribution of plankton and TEP in the Gulf of Cádiz (SW Iberian Peninsula), J. Plankton Res., 24, 817-833, 2002.

Gärdes, A., Iversen, M. H., Grossart, H. P., Passow, U., and Ullrich, M. S.: Diatom-associated bacteria are required for aggregation of Thalassiosira weissflogii, ISME J., 5, 436-445, https://doi.org/10.1038/ismej.2010.145, 2011.

Gasol, J. M. and Morán, X. A. G.: Effects of filtration on bacterial activity and picoplankton community structure as assessed by flow cytometry, Aquat. Microb. Ecol., 16, 251-264, 1999.

Gordon, A.: Brazil-Malvinas Conlluence - 1984, Deep-Sea Res., 36, 359-384, 1989.

Grossart, H. P., Berman, T., Simon, M., and Pohlmann, K.: Occurrence and microbial dynamics of macroscopic organic aggregates (lake snow) in Lake Kinneret, Israel, in fall, Aquat. Microb. Ecol., 14, 59-67, https://doi.org/10.3354/ame014059, 1998.

Grossart, H. P., Czub, G., and Simon, M.: Algae-bacteria interactions and their effects on aggregation and organic matter flux in the sea, Environ. Microbiol., 8, 1074-1084, https://doi.org/10.1111/j.1462-2920.2006.00999.x, 2006.

Guerrini, F., Mazzotti, A., Boni, L., and Pistocchi, R.: Bacterialalgal interactions in polysaccharide production, Aquat. Microb. Ecol., 15, 247-253, 1998.

Hansen, H. P. and Grasshoff, K.: Procedures for the automated determination of seawater constituents, in: Methods of seawater analysis, 2nd Edn., Verlag Chemie, Weinheim, 362-379, 1983.

Harlay, J., De Bodt, C., Engel, A., Jansen, S., d'Hoop, Q., Piontek, J., Van Oostende, N., Groom, S., Sabbe, K., and Chou, L.: Abundance and size distribution of transparent exopolymer particles (TEP) in a coccolithophorid bloom in the northern Bay of Biscay, Deep-Sea Res. Pt. I, 56, 1251-1265, https://doi.org/10.1016/j.dsr.2009.01.014, 2009.

Harlay, J., Borges, A. V., Van Der Zee, C., Delille, B., Godoi, R. H. M., Schiettecatte, L. S., Roevros, N., Aerts, K., Lapernat, P. E., Rebreanu, L., Groom, S., Daro, M. H., Van Grieken, R., and Chou, L.: Biogeochemical study of a coccolithophore bloom in the northern Bay of Biscay (NE Atlantic Ocean) in June 2004, Prog. Oceanogr., 86, 317-336, https://doi.org/10.1016/j.pocean.2010.04.029, 2010.

Heinonen, K. B., Ward, J. E., and Holohan, B. A.: Production of transparent exopolymer particles (TEP) by benthic suspension feeders in coastal systems, J. Exp. Mar. Biol. Ecol., 341, 184195, https://doi.org/10.1016/j.jembe.2006.09.019, 2007.

Hong, Y., Smith, W. O., and White, A.-M.: Studies of transparent exopolymer particles (TEP) produced in the Ross Sea (Antarctica) and by Phaeocytis antarctica (Prymnesiophyceae), J. Phycol., 33, 368-376, 1997.

Iuculano, F., Duarte, C. M., Marbà, N., and Agustí, S.: Seagrass as major source of transparent exopolymer particles in the oligotrophic Mediterranean coast, Biogeosciences, 14, 5069-5075, https://doi.org/10.5194/bg-14-5069-2017, 2017a.

Iuculano, F., Mazuecos, I. P., Reche, I., and Agusti, S.: Prochlorococcus as a Possible Source for Transparent Exopolymer Particles (TEP), Front Microbiol., 8, 709, https://doi.org/10.3389/fmicb.2017.00709, 2017b.

Jähmlich, S., Thomsen, L., and Graf, G.: Factors controlling aggregate formation in the benthic boundary layer of the Mecklenburg Bight (western Baltic Sea), J. Sea Res., 41, 245-254, 1998.

Jennings, M. K., Passow, U., Wozniak, A. S., and Hansell, D. A.: Distribution of transparent exopolymer particles (TEP) across an organic carbon gradient in the western North Atlantic Ocean, Mar. Chem., 190, 1-12, https://doi.org/10.1016/j.marchem.2017.01.002, 2017.

Kiorboe, T., Hansen, J. L. S., Alldredge, A. L., Jackson, G. A., Passow, U., Dam, H. G., Drapeau, D. T., Waite, A., and Garcia, C. M.: Sedimentation of phytoplankton during a diatom bloom: Rates and mechanisms, Journal of Marine Science, 54, 11231148, 1996.

Klein, C., Claquin, P., Pannard, A., Napoléon, C., Le Roy, B., and Véron, B.: Dynamics of soluble extracellular polymericsubstances and transparent exopolymer particle pools in coastal ecosystems, Mar. Ecol.-Prog. Ser., 427, 13-27, https://doi.org/10.3354/meps09049, 2011.

Kodama, T., Kurogi, H., Okazaki, M., Jinbo, T., Chow, S., Tomoda, T., Ichikawa, T., and Watanabe, T.: Vertical distribution of transparent exopolymer particle (TEP) concentration in the oligotrophic western tropical North Pacific, Mar. Ecol.-Prog. Ser., 513, 29-37, https://doi.org/10.3354/meps10954, 2014.

Kozlowski, W. and Vernet, M.: Palmer LTER: Predominance of cryptomonads and diatoms in antarctic coastal waters, Antarct. J. US, 30, 267-268, 1995.

Kozlowski, W. A., Deutschman, D., Garibotti, I., Trees, C., and Vernet, M.: An evaluation of the application of CHEMTAX to Antarctic coastal pigment data, Deep-Sea Res. Pt. I, 58, 350364, https://doi.org/10.1016/j.dsr.2011.01.008, 2011.

Kumar, M. D., Sarma, V. V. S. S., Ramaiah, N., Gauns, M., and de Sousa, S. N.: Biogeochemical significance of transport exopolymer particles in the Indian Ocean, Geophys. Res. Lett., 25, 81-84, https://doi.org/10.1029/97gl03481, 1998.

Kuznetsova, M., Lee, C., and Aller, J.: Characterization of the proteinaceous matter in marine aerosols, Mar. Chem., 96, 359-377, https://doi.org/10.1016/j.marchem.2005.03.007, 2005.

Lebaron, P., Servais, P., Agogue, H., Courties, C., and Joux, F.: Does the high nucleic acid content of individual bacterial cells allow us to discriminate between active cells and inactive cells in aquatic systems?, Appl. Environ. Microb., 67, 1775-1782, https://doi.org/10.1128/AEM.67.4.1775-1782.2001, 2001.

Leblanc, K., Hare, C. E., Feng, Y., Berg, G. M., DiTullio, G. R., Neeley, A., Benner, I., Sprengel, C., Beck, A., Sanudo-Wilhelmy, S. A., Passow, U., Klinck, K., Rowe, J. M., Wilhelm, S. W., 
Brown, C. W., and Hutchins, D. A.: Distribution of calcifying and silicifying phytoplankton in relation to environmental and biogeochemical parameters during the late stages of the 2005 North East Atlantic Spring Bloom, Biogeosciences, 6, 21552179, https://doi.org/10.5194/bg-6-2155-2009, 2009.

Leck, C., Gao, Q., Mashayekhy Rad, F., and Nilsson, U.: Size-resolved atmospheric particulate polysaccharides in the high summer Arctic, Atmos. Chem. Phys., 13, 12573-12588, https://doi.org/10.5194/acp-13-12573-2013, 2013.

Ling, S. and Alldredge, A. L.: Does the marine copepod Calanus pacificus consume transparent exopolymer particles (TEP)?, J. Plankton Res., 25, 507-515, 2003.

Logan, B. E., Passow, U., Alldredge, A. L., Grossart, H. P., and Simon, M.: Rapid formation and sedimentation of large aggregates is predictable from coagulation rates (half-lives) of transparent exopolymer particles (TEP), Deep-Sea Res. Pt. II, 42, 203-214, 1995.

Long, R. A. and Azam, F.: Abundant protein-containing particles in the sea, Aquat. Microb. Ecol., 10, 213-221, 1996.

Longhurst, A. R.: Ecological Geography of the Sea, 2nd Edn., Academic Press, San Diego, 402 pp., 1998.

López-Sandoval, D. C., Fernández, A., and Marañón, E.: Dissolved and particulate primary production along a longitudinal gradient in the Mediterranean Sea, Biogeosciences, 8, 815-825, https://doi.org/10.5194/bg-8-815-2011, 2011.

Mari, X. and Kiorboe, T.: Abundance, size distribution and bacterial colonization of transparent exopolymeric particles (TEP) during spring in the Kattegat, J. Plankton Res., 18, 969-986, 1996.

Mari, X., Rassoulzadegan, F., Brussaard, C. P. D., and Wassmann, P.: Dynamics of transparent exopolymeric particles (TEP) production by Phaeocystis globosa under N- or P-limitation: a controlling factor of the retention/export balance, Harmful Algae, 4, 895-914, https://doi.org/10.1016/j.hal.2004.12.014, 2005.

Mari, X., Passow, U., Migon, C., Burd, A. B., and Legendre, L.: Transparent exopolymer particles: Effects on carbon cycling in the ocean, Prog. Oceanogr., 151, 13-37, https://doi.org/10.1016/j.pocean.2016.11.002, 2017.

Mazuecos, I. P.: Exopolymer particles in the ocean: in the ocean: Production by microorganisms, carbon export and by microorganisms, carbon export and ation mesopelagic respiration, $\mathrm{PhD}$ thesis, University of Granada, Spain, 281 pp., 2015.

Menden-Deuer, S. and Lessard, E. J.: Carbon to volume relationships for dinoflagellates, diatoms, and other protist plankton, Limnol. Oceanogr., 45, 569-579, 2000.

Myklestad, S.: Production of carbohydrates by marine planktonic diatoms, J. Exp. Mar. Biol. Ecol., 29, 161-179, 1977.

Nagata, T.: Production mechanisms of dissolved organic matter, in: Microbial Ecology of the Oceans, edited by: Kirchman, D. L., Wiley-Liss Inc., New York, 121-152, 2000.

Nicolaus, B., Panico, A., Lama, L., Romano, I., Manca, M. C., De Giulio, A., and Gambacorta, A.: Chemical composition and production of exopolysaccharides from representative members of heterocystous and non-heterocystous cyanobacteria, Phytochemistry, 52, 639-647, 1999.

Norland, S.: The relationship between biomass and volume of bacteria, in: Handbook of methods in aquatic microbial ecology, edited by: Kemp, P. F., Sherr, B. F., Sherr, E. B., and Cole, J. J., Lewis Publishers, Boca Raton, 303-307, 1993.
Olson, R. J., Zettler, E. R., and DuRand, M. D.: Phytoplankton analysis using flow cytometry, in: Handbook of Methods in Aquatic Microbial Ecology, edited by: Kemp, P. F., Sherr, B. F., Sherr, E. B., and Cole, J. J., Lewis Publishers, Boca Raton, 1993.

Orellana, M. V. and Verdugo, P.: Ultraviolet radiation blocks the organic carbon exchange between the dissolved phase and the gel phase in the ocean, Limnol. Oceanogr., 48, 1618-1623, 2003.

Orellana, M. V., Matrai, P. A., Leck, C., Rauschenberg, C. D., Lee, A. M., and Coz, E.: Marine microgels as a source of cloud condensation nuclei in the high Arctic, P. Natl. Acad. Sci. USA, 108, 13612-13617, https://doi.org/10.1073/pnas.1102457108, 2011.

Ortega-Retuerta, E., Passow, U., Duarte, C. M., and Reche, I.: Effects of ultraviolet $B$ radiation on (not so) transparent exopolymer particles, Biogeosciences, 6, 3071-3080, https://doi.org/10.5194/bg-6-3071-2009, 2009a.

Ortega-Retuerta, E., Reche, I., Pulido-Villena, E., Agustí, S., and Duarte, C. M.: Uncoupled distributions of transparent exopolymer particles (TEP) and dissolved carbohydrates in the Southern Ocean, Mar. Chem., 115, 59-65, https://doi.org/10.1016/j.marchem.2009.06.004, 2009b.

Ortega-Retuerta, E., Duarte, C. M., and Reche, I.: Significance of bacterial activity for the distribution and dynamics of transparent exopolymer particles in the Mediterranean sea, Microb. Ecol., 59, 808-818, https://doi.org/10.1007/s00248-010-9640-7, 2010.

Ortega-Retuerta, E., Sala, M. M., Borrull, E., Mestre, M., Aparicio, F. L., Gallisai, R., Antequera, C., Marrase, C., Peters, F., Simo, R., and Gasol, J. M.: Horizontal and Vertical Distributions of Transparent Exopolymer Particles (TEP) in the NW Mediterranean Sea Are Linked to Chlorophyll a and $\mathrm{O}_{2}$ Variability, Front. Microbiol., 7, 2159, https://doi.org/10.3389/fmicb.2016.02159, 2017.

Ortega-Retuerta, E., Marrase, C., Munoz-Fernandez, A., Sala, M. M., Simo, R., and Gasol, J. M.: Seasonal dynamics of transparent exopolymer particles (TEP) and their drivers in the coastal NW Mediterranean Sea, Sci. Total Environ., 631-632, 180-190, https://doi.org/10.1016/j.scitotenv.2018.02.341, 2018.

Palma, E. D., Matano, R. P., and Piola, A. R.: A numerical study of the Southwestern Atlantic Shelf circulation: Stratified ocean response to local and offshore forcing, J. Geophys. Res., 113, C11010, https://doi.org/10.1029/2007jc004720, 2008.

Parinos, C., Gogou, A., Krasakopoulou, E., Lagaria, A., Giannakourou, A., Karageorgis, A. P., and Psarra, S.: Transparent Exopolymer Particles (TEP) in the NE Aegean Sea frontal area: Seasonal dynamics under the influence of Black Sea water, Cont. Shelf Res., 149, 112-123, https://doi.org/10.1016/j.csr.2017.03.012, 2017.

Partensky, F., Hess, W. R., and Vaulot, D.: Prochlorococcus, a Marine Photosynthetic Prokaryote of Global Significance, Microbiol. Mol. Biol. R., 63, 106-137, 1999.

Passow, U.: Formation of transparent exopolymer particles, TEP, from dissolved precursor material, Mar. Ecol.-Prog. Ser., 192, 111, 2000.

Passow, U.: Transparent exopolymer particles (TEP) in aquatic environments, Prog. Oceanogr., 55, 287-333, 2002a.

Passow, U.: Production of transparent exopolymer particles (TEP) by phyto- and bacterioplankton, Mar. Ecol.-Prog. Ser., 236, 1-12, 2002b. 
Passow, U. and Alldredge, A. L.: Distribution,size and bacterial colonization of transparent exopolymer particles (TEP) in the ocean, Mar. Ecol.-Prog. Ser., 113, 185-198, 1994.

Passow, U. and Alldredge, A. L.: A dye-binding assay for the spectrophotometric measurement of transparent exopolymer particles (TEP), Limnol. Oceanogr., 40, 1326-1335, 1995.

Passow, U. and Alldredge, A. L.: Do transparent exopolymer particles (TEP) inhibit grazing by the euphausiid Euphausia pacifica?, J. Plankton Res., 21, 2203-2217, 1999.

Passow, U., Kozlowski, W., and Vernet, M.: Distribution of Transparent Exopolymer Particles (TEP) during summer at a permanent station in Antarctica, Antarct. J. US, 30, 265-266, 1995.

Passow, U., Shipe, R. F., Murray, A., Pak, D. K., Brzezinski, M. A., and Alldredge, A. L.: The origin of transparent exopolymer particles (TEP) and their role in the sedimentation of particulate matter, Cont. Shelf Res., 21, 327-346, 2001.

Pedrotti, M. L., Peters, F., Beauvais, S., Vidal, M., Egge, J., Jacobsen, A., and Marrasé, C.: Effects of nutrients and turbulence on the production of transparent exopolymer particles: a mesocosm study, Mar. Ecol.-Prog. Ser., 419, 57-69, https://doi.org/10.3354/meps08840, 2010.

Pernice, M. C., Forn, I., Gomes, A., Lara, E., Alonso-Saez, L., Arrieta, J. M., del Carmen Garcia, F., Hernando-Morales, V., MacKenzie, R., Mestre, M., Sintes, E., Teira, E., Valencia, J., Varela, M. M., Vaque, D., Duarte, C. M., Gasol, J. M., and Massana, R.: Global abundance of planktonic heterotrophic protists in the deep ocean, ISME J., 9, 782-792, https://doi.org/10.1038/ismej.2014.168, 2015.

Peterson, R. G. and Stramma, L.: Upper-level circulation in the South Atlantic Ocean, Prog. Oceanogr., 26, 1-73, 1991.

Piola, A. R.: The influence of the Plata River discharge on the western South Atlantic shelf, Geophys. Res. Lett., 32, https://doi.org/10.1029/2004g1021638, 2005.

Piola, A. R. and Gordon, A. L.: Intermediate waters in the southwest South Atlantic, Deep-Sea Res., 36, 1-16, 1989.

Prieto, L., Sommer, F., Stibor, H., and Koeve, W.: Effects of planktonic copepods on transparent exopolymeric particles (TEP) abundance and size spectra, J. Plankton Res., 5, 515-525, 2001.

Prieto, L., Navarro, G., Cózar, A., Echevarría, F., and García, C. M.: Distribution of TEP in the euphotic and upper mesopelagic zones of the southern Iberian coasts, Deep-Sea Res. Pt. II, 53, 1314-1328, https://doi.org/10.1016/j.dsr2.2006.03.009, 2006.

Radic, T., Kraus, R., Fuks, D., Radic, J., and Pecar, O.: Transparent exopolymeric particles' distribution in the northern Adriatic and their relation to microphytoplankton biomass and composition, Sci. Total Environ., 353, 151-161, https://doi.org/10.1016/j.scitotenv.2005.09.013, 2005.

Radic, T., Ivancic, I., Fuks, D., and Radic, J.: Marine bacterioplankton production of polysaccharidic and proteinaceous particles under different nutrient regimes, FEMS Microbiol. Ecol., 58, 333-342, https://doi.org/10.1111/j.1574-6941.2006.00176.x, 2006.

Ramaiah, N. and Furuya, K.: Seasonal variations in phytoplankton composition and transparent exopolymer particles in a eutrophicated coastal environment, Aquat. Microb. Ecol., 30, 6982, 2002.

Ramaiah, N., Sarma, V. V. S. S., Gauns, M., Kumar, M. D., and Madhupratap, M.: Abundance and relationship of bacteria with transparent exopolymer particles during the 1996 summer mon- soon in the Arabian Sea, Proc. Indian Acad. Sci.-Earth and Planetary Sciences, 109, 443-451, 2000.

Ramaiah, N., Yoshikawa, T., and Furuya, K.: Temporal variations in transparent exopolymer particles (TEP) associated with a diatom spring bloom in a subarctic ria in Japan, Mar. Ecol.-Prog. Ser., 212, 79-88, https://doi.org/10.3354/meps212079, 2001.

Ramaiah, N., Takeda, S., Furuya, K., Yoshimura, T., Nishioka, J., Aono, T., Nojiri, Y., Imai, K., Kudo, I., Saito, H., and Tsuda, A.: Effect of iron enrichment on the dynamics of transparent exopolymer particles in the western subarctic Pacific, Prog. Oceanogr., 64, 253-261, https://doi.org/10.1016/j.pocean.2005.02.012, 2005.

Riebesell, U., Reigstad, M., Wassmann, P., Noji, T., and Passow, U.: On the trophic fate of Phaeocystis pouchetii (Hariot): VI. Significance of Phaeocystis-derived mucus for vertical flux, J. Sea Res., 33, 193-203, 1995.

RStudio Team: RStudio: Integrated Development for R. RStudio, Inc., Boston, MA, available at: http://www.rstudio.com (last access: 28 January 2019), 2016.

Schartau, M., Engel, A., Schröter, J., Thoms, S., Völker, C., and Wolf-Gladrow, D.: Modelling carbon overconsumption and the formation of extracellular particulate organic carbon, Biogeosciences, 4, 433-454, https://doi.org/10.5194/bg-4-433-2007, 2007.

Scoullos, M., Plavšić, M., Karavoltsos, S., and Sakellari, A.: Partitioning and distribution of dissolved copper, cadmium and organic matter in Mediterranean marine coastal areas: The case of a mucilage event, Estuar. Coast. Shelf S., 67, 484-490, https://doi.org/10.1016/j.ecss.2005.12.007, 2006.

Servais, P., Courties, C., Lebaron, P., and Troussellier, M.: Coupling Bacterial Activity Measurements with Cell Sorting by Flow Cytometry, Microb. Ecol., 38, 180-189, https://doi.org/10.1007/s002489900160, 1999.

Shibata, A., Kogure, K., Koike, I., and Ohwada, K.: Formation of submicron colloidal particles from marine bacteria by viral infection, Mar. Ecol.-Prog. Ser., 155, 303-307, 1997.

Simó, R., Vila-Costa, M., Alonso-Sáez, L., Cardelús, C., Guadayol, Ò., Vázquez-Domínguez, E., and Gasol, J. M.: Annual DMSP contribution to $\mathrm{S}$ and $\mathrm{C}$ fluxes through phytoplankton and bacterioplankton in a NW Mediterranean coastal site, Aquat. Microb. Ecol., 57, 43-55, https://doi.org/10.3354/ame01325, 2009.

Stoderegger, K. and Herndl, G. J.: Production and release of bacterial capsular material and its subsequent utilization by marine bacterioplankton, Limnol. Oceanogr., 43, 877-884, 1998.

Sugimoto, K., Fukuda, H., Baki, M. A., and Koike, I.: Bacterial contributions to formation of transparent exopolymer particles (TEP) and seasonal trends in coastal waters of Sagami Bay, Japan, Aquat. Microb. Ecol., 46, 31-41, https://doi.org/10.3354/ame046031, 2007.

Sun, C.-C., Wang, Y.-S., Li, Q. P., Yue, W.-Z., Wang, Y.-T., Sun, F.L., and Peng, Y.-L.: Distribution characteristics of transparent exopolymer particles in the Pearl River estuary, China, J. Geophys. Res.-Biogeo., 117, 1-12, https://doi.org/10.1029/2012jg001951, 2012.

Thuy, N. T., Lin, J. C., Juang, Y., and Huang, C.: Temporal variation and interaction of full size spectrum Alcian blue stainable materials and water quality parameters in a reservoir, Chemosphere, 131, 139-148, https://doi.org/10.1016/j.chemosphere.2015.03.023, 2015. 
Trabelsi, L., Ben Ouada, H., Bacha, H., and Ghoul, M.: Combined effect of temperature and light intensity on growth and extracellular polymeric substance production by the cyanobacterium Arthrospira platensis, J. Appl. Phycol., 21, 405-412, https://doi.org/10.1007/s10811-008-9383-8, 2008.

Utermöhl, H.: Zur Vervollkommnung der quentitativen Phytoplankton-Methodik, Mitteilungen der International Vereinigung fur heorestische und Angewandte Limnologie, 9, $1-38,1958$.

Van Oostende, N., Harlay, J., Vanelslander, B., Chou, L., Vyverman, W., and Sabbe, K.: Phytoplankton community dynamics during late spring coccolithophore blooms at the continental margin of the Celtic Sea (North East Atlantic, 2006-2008), Prog. Oceanogr., 104, 1-16, https://doi.org/10.1016/j.pocean.2012.04.016, 2012.

Vardi, A., Haramaty, L., Van Mooy, B. A., Fredricks, H. F., Kimmance, S. A., Larsen, A., and Bidle, K. D.: Host-virus dynamics and subcellular controls of cell fate in a natural coccolithophore population, P. Natl. Acad. Sci. USA, 109, $19327-$ 19332, https://doi.org/10.1073/pnas.1208895109, 2012.

Wild, C.: Effekte von "marine snow" - Sedimentation auf Steinkorallen (Hexacorallia,Scleractinia) des Great Barrier Reef, Australien, Department of Biology and Chemistry, University of Bremen, 110 pp., 2000.

Wilson, T. W., Ladino, L. A., Alpert, P. A., Breckels, M. N., Brooks, I. M., Browse, J., Burrows, S. M., Carslaw, K. S., Huffman, J. A., Judd, C., Kilthau, W. P., Mason, R. H., McFiggans, G., Miller, L. A., Najera, J. J., Polishchuk, E., Rae, S., Schiller, C. L., Si, M., Temprado, J. V., Whale, T. F., Wong, J. P., Wurl, O., Yakobi-Hancock, J. D., Abbatt, J. P., Aller, J. Y., Bertram, A. K., Knopf, D. A., and Murray, B. J.: A marine biogenic source of atmospheric ice-nucleating particles, Nature, 525, 234-238, https://doi.org/10.1038/nature14986, 2015.
Wurl, O., Miller, L., Röttgers, R., and Vagle, S.: The distribution and fate of surface-active substances in the seasurface microlayer and water column, Mar. Chem., 115, 1-9, https://doi.org/10.1016/j.marchem.2009.04.007, 2009.

Wurl, O., Miller, L., and Vagle, S.: Production and fate of transparent exopolymer particles in the ocean, J. Geophys. Res., 116 C00H13, https://doi.org/10.1029/2011jc007342, 2011a.

Wurl, O., Wurl, E., Miller, L., Johnson, K., and Vagle, S.: Formation and global distribution of sea-surface microlayers, Biogeosciences, 8, 121-135, https://doi.org/10.5194/bg-8-1212011, 2011b.

Wurl, O., Stolle, C., Van Thuoc, C., The Thu, P., and Mari, X.: Biofilm-like properties of the sea surface and predicted effects on air-sea $\mathrm{CO}_{2}$ exchange, Prog. Oceanogr., 144, 15-24, https://doi.org/10.1016/j.pocean.2016.03.002, 2016.

Yamada, Y., Fukuda, H., Uchimiya, M., Motegi, C., Nishino, S., Kikuchi, T., and Nagata, T.: Localized accumulation and a shelfbasin gradient of particles in the Chukchi Sea and Canada Basin, western Arctic, J. Geophys. Res.-Oceans, 120, 46384653, https://doi.org/10.1002/2015jc010794, 2015.

Yentsch, C. S. and Menzel, D. W.: A method for the determination of phytoplankton chlorophyll and phaeophytin by fluorescence, Deep-Sea Res. Pt. I, 10, 221-231, 1963.

Zhou, J., Mopper, K., and Passow, U.: The role of surface-active carbohydrates in the formation of transparent exopolymer particles by bubble adsorption of seawater, Limnol. Oceanogr., 43, 1860-1871, 1998.

Zubkov, M. V., Sleigh, M. A., Tarran, G. A., Burkill, P. H., Raymond, J. A., and Leakey, R. J. G.: Picoplanktonic community structure on an Atlantic transect from $50^{\circ} \mathrm{N}$ to $50^{\circ} \mathrm{S}$, Deep-Sea Res. Pt. I, 45, 1339-1355, 1998. 